\title{
Ammonia Concentrations over Europe - Application of the WRF-Chem Model Supported with Dynamic Emission
}

\author{
Malgorzata Werner ${ }^{1 *}$, Maciej Kryza ${ }^{1}$, Camilla Geels ${ }^{2}$, \\ Thomas Ellermann², Carsten Ambelas Skjøth ${ }^{3}$ \\ ${ }^{1}$ Department of Climatology and Atmosphere Protection, University of Wrocław, Wrocław, Poland \\ ${ }^{2}$ Department of Environmental Science, Aarhus University, Roskilde, Denmark \\ ${ }^{3}$ Institute of Science and the Environment, University of Worcester, Worcester, United Kingdom
}

Received: 31 August 2016

Accepted: 22 November 2016

\begin{abstract}
Our study focuses on the application of a static and dynamic ammonia emissions based on a Europe-wide default setting into the weather research and forecasting chemistry model (WRF-Chem), and the influence on the simulated ammonia concentrations and overall model performance. The WRF-Chem model was run twice for all of Europe at a spatial resolution of $36 \times 36 \mathrm{~km}$ for the year 2012. In the first simulation we used a static emissions approach (the "BASE" simulation) and in the second simulation we used dynamic ammonia emissions (the "DYNAMIC" simulation). Both simulations underestimate measured concentrations of $\mathrm{NH}_{3}$ for all seasons, have similar NMGE (about $0.7 \mu \mathrm{g} \mathrm{m}^{-3}$ ), and model hourly ammonia peaks that shift toward the afternoon hours if compared with measurements. However, for all temporal resolutions, normalised mean gross error in winter and summer is lower for DYNAMIC than for BASE. The DYNAMIC simulation also generally gives worse performance in spring for each temporal resolution. For further improvement of the modelled ammonia concentrations with WRF-Chem we suggest using a nested approach with higher spatial resolution, which will lead to better separation of the ammonia source regions from surrounding areas and take into account national practices and regulations in the emissions model, eventually only in the nested model domain.
\end{abstract}

Keywords: ammonia, emissions, concentrations, WRF-Chem, modelling

\section{Introduction}

Ammonia $\left(\mathrm{NH}_{3}\right)$ is the most abundant form of reduced nitrogen in the gas-phase within the atmosphere [1]. Ammonia contributes to both the formation of particulate

*e-mail: malgorzata.werner@uwr.edu.pl matter (PM) and the deposition of reactive nitrogen to the environment [2-4]. Ammonia plays a decisive role in particulate matter formation chemistry by determining the amount of ammonium sulphate and ammonium nitrate as PM constituents [5]. Erisman et al. [6] estimate that $\mathrm{NH}_{3}$ emissions from agriculture give a substantial contribution (13\%) to the PM concentration in Europe and thereby adds significantly to the external costs related 
to air pollution in Europe [7]. The deposition of nitrogen in the form of ammonia can result in eutrophication of sensitive ecosystems and to acidification of the soil [8]. An enhanced load of nitrogen in terrestrial ecosystems has been found to correlate with loss of biodiversity [9] and can increase ecosystem vulnerability to extreme weather and insect attacks [10]. Despite its importance, there are still many knowledge gaps on ammonia. Long-term observational data series are in general scarce compared to, e.g., ozone [11], and hourly observations of ammonia are even more rare due to their expense and complexity caused by feedback mechanisms [12] and general comprehensive experimental setups [e.g., 13]. Agriculture was responsible for $94 \%$ of the total $\mathrm{NH}_{3}$ emissions in the EU in 2010 (European Environment Agency, www.eea. europa.eu).

Agricultural emissions are related to farm buildings, manure, fertilisers, and grazing animals, and are strongly influenced by climate and weather [14]. $\mathrm{NH}_{3}$ emissions varies primarily with temperature and air velocity [15]. The volatilization potential nearly doubles for every $5^{\circ} \mathrm{C}$ and varies significantly throughout the day and season [16-17] and are beginning to be used in regional chemical transport models. However, such models have typically applied simpler emission factors to upscale the main $\mathrm{NH}_{3}$ emission terms. While this approach has successfully simulated the main spatial patterns on local to global scales, it fails to address the environment- and climatedependence of emissions. To handle these issues, we outline the basis for a new modelling paradigm where both $\mathrm{NH}_{3}$ emissions and deposition are calculated online according to diurnal, seasonal and spatial differences in meteorology. We show how measurements reveal a strong, but complex pattern of climatic dependence, which is increasingly being characterized using groundbased $\mathrm{NH}_{3}$ monitoring and satellite observations, while advances in process-based modelling are illustrated for agricultural and natural sources, including a global application for seabird colonies. A future architecture for $\mathrm{NH}_{3}$ emission-deposition modelling is proposed that integrates the spatio-temporal interactions, and provides the necessary foundation to assess the consequences of climate change. Based on available measurements, a first empirical estimate suggests that $5 \backslash \mathrm{u} 00 \mathrm{~b} 0 \mathrm{C}$ warming would increase emissions by 42 per cent $\left(28-67 \%\right.$. $\mathrm{NH}_{3}$ emissions is also controlled by water availability, which allows nitrogen compounds to dissolve, be taken up by organisms, and be released through decomposition [17] and are beginning to be used in regional chemical transport models. However, such models have typically applied simpler emission factors to upscale the main $\mathrm{NH}_{3}$ emission terms. While this approach has successfully simulated the main spatial patterns on local to global scales, it fails to address the environment- and climatedependence of emissions. To handle these issues, we outline the basis for a new modelling paradigm where both $\mathrm{NH}_{3}$ emissions and deposition are calculated online according to diurnal, seasonal and spatial differences in meteorology. We show how measurements reveal a strong, but complex pattern of climatic dependence, which is increasingly being characterized using ground-based $\mathrm{NH}_{3}$ monitoring and satellite observations, while advances in process-based modelling are illustrated for agricultural and natural sources, including a global application for seabird colonies. A future architecture for $\mathrm{NH}_{3}$ emissiondeposition modelling is proposed that integrates the spatio-temporal interactions, and provides the necessary foundation to assess the consequences of climate change. Based on available measurements, a first empirical estimate suggests that $5 \backslash \mathrm{u} 00 \mathrm{~b} 0 \mathrm{C}$ warming would increase emissions by 42 per cent (28-67\%. The regional variation reflects local production methods and agricultural practice, which to a large extent is governed by regional scale climate conditions [18], but also specific national regulations [19]. Despite these well-known dependencies of climate and meteorology on ammonia emissions, the emissions are handled in a very simplified manner in most atmospheric models [18], and implementing specific national regulations into European-wide emissions models appears to be a complex question that remains to be solved [19]. Many integrated effects of meteorology and climate on ammonia remain to be studied and this has been highlighted by the IPCC [20] as an area that is poorly understood. Improvement of representation of processes that lead to ammonia emissions in atmospheric models has therefore frequently been highlighted as an area that needs scientific attention $[12,17]$.

Recently, Sutton et al. [17] suggested two long-term goals on ammonia modelling within CTMs. Firstly, the same meteorological data should be used to drive emissions, chemistry-transport, and bi-directional exchange. Secondly, the emissions should be calculated online in the CTMs, whereby the feedback between the ammonia emissions and climate can be included. Recently, Zhu et al. [21] indicated that updates to the governing processes on both dynamics and physics concerning $\mathrm{NH}_{3}$ need improvement. Previous studies have shown significant improvements in model performance by replacing static seasonal variations by a dynamic approach that accounts for physical processes like volatilization of $\mathrm{NH}_{3}$ [18]. Similarly, other modelling studies have shown that some atmospheric components are sensitive to the formulation of the ammonia emissions [22]. This highlights the need for a better understanding of ammonia emissions and how this is implemented in CTM models.

Recent studies on modelling atmospheric ammonia with CTMs have focused on the implementation of the bidirectional $\mathrm{NH} 3$ exchange between the atmosphere and the surface $[21,23,24]$, the impact of ammonia emissions on concentrations of secondary inorganic aerosols [3, $5,25]$, investigations of the role of different natural emissions sources of ammonia [26-27], and improvements in the representation of ammonia emissions from different agricultural activities, e.g., livestock emissions [21] and mineral fertilizers [25]. Focus on the processes that generate ammonia emissions and the initial dispersion has, however, had limited attention in the development of existing CTM models. Addressing this knowledge 
gap is one of the objectives in Effects of Climate Change on Air Pollution and Response Strategies for European Ecosystems (ECLAIRE), which is a project founded by the Seventh Framework Programme for Research and Technological Development.

In our study the European dynamic ammonia emissions model [18] was for the first time applied within a chemical transport model (CTM) for all of Europe and evaluated for this region. The paper of Skjøth et al. [18] provided the emissions model code for Europe and included a test of the model over Northern Europe (Denmark, Germany, and part of the surrounding countries) using the Danish Eulerian Hemispheric Model. The focus on Northern Europe was partly due to a lack of input data and limitations in the emissions model to operate in all major European landscapes [18]. In the present study, the dynamic emissions model was modified for a European-wide application, including development of the needed emissions input data. Application of the emissions model with WRF-Chem for study of ammonia for this large area was undertaken in our study for the first time. The models have been run for the year 2012 and we used observations with hourly, daily, and monthly temporal resolutions of ammonia and daily observations of aerosols $\left(\mathrm{NH}_{4}^{+}, \mathrm{NO}_{3}^{-}, \mathrm{SO}_{4}^{2-}\right)$ to evaluate the results. In order to better understand the model limitations, the evaluation was done separately for four seasons (winter, spring, summer, and autumn).

\section{Data and Methods}

\section{The WRF-Chem Model}

The weather research and forecasting model coupled online with chemistry (WRF-Chem) was used to simulate the meteorological conditions and ammonia concentrations over Europe for all of 2012. A complete description of the model is given by Grell et al. [28] and Fast et al. [29]. The GFS FNL global analysis, created and maintained by the National Centre for Environmental Prediction (NCEP), with a spatial resolution of $1^{\circ} \times 1^{\circ}$ (longitude-latitude) and a vertical resolution of 27 pressure levels, were used to define the initial and boundary meteorological conditions. The main setup and the physical and chemical schemes used in this study are listed in Table 1. The last five days of year 2011 were used as a spin up for the chemistry as in Forkel et al. [30]. We used the RADM2 gas phase chemistry [31] and the MADE/ SORGAM aerosol module [32-33] with the aerosol direct and indirect radiative effect included [19, 34]. Chemistry transport modelling in general benefits from a high number of layers within the planetary boundary layer (PBL) [35], especially near the surface, when calculations concern gases with a fast deposition velocity (e.g., ammonia) [36]. Thus, we adjusted the vertical resolution in WRFChem by decreasing the thickness of the lowest layer from 53 to $20 \mathrm{~m}$ and doubling the number of layers within the first 1,015 m, which gives 48 layers in total.
The WRF-Chem model has been extensively used and evaluated for both meteorological and air quality studies in Europe. The model performance for meteorology affects both the air quality results and the calculated emissions. Several studies focused on all of Europe and reported biases for both air temperature and precipitation (Miglietta et al. [37], Katragkou et al. [38], Wałaszek et al. [39], Kim et al. [40], and Warrach-Sagi et al. [41]). Recent findings provided by Skjøth et al. [42] show that the bias in air temperature at $2 \mathrm{~m}$ varies spatially and seasonally. These biases are significant (up to $+2.0 \mathrm{~K}$ in eastern Europe during summer and autumn and $-2.0 \mathrm{~K}$ in southern Europe in winter), and might affect, e.g., online calculated emissions and the processes in vegetation models. Similar findings are reported by Kryza et al. [43] for the area of Poland, where the air temperature bias is low in winter (mean bias $-0.6 \mathrm{~K}$ ), but where summer temperatures are significantly overestimated (up to $+1.0 \mathrm{~K}$ ). A bias in WRFcalculated air temperatures were also reported by Mooney et al. [44] and Miglietta et al. [37]. The model performs well at simulating wind speed for Europe, with mean bias not exceeding $0.5 \mathrm{~m} \mathrm{~s}-1$ [37, 45-47], which is the second variable affecting ammonia emissions in this study.

The WRF-Chem model was run twice in our study. In the first simulation we ran WRF-Chem using the TNO MACC II emissions data set with $1 / 8^{\circ}$ x $1 / 16^{\circ}$ spatial resolution [48] and a temporal emissions profile that includes a seasonal variation that changes each month, but the seasonal variation is the same throughout the entire model domain. This simulation is subsequently referred to as "BASE." In the second simulation we ran the WRF-Chem model with hourly variations in ammonia emissions for all of 2012 by using a similar approach as for the Danish Eulerian Hemispheric Model [49], and the ammonia emissions model uses gridded hourly meteorology from WRF-Chem to simulate the hourly

Table 1. Model components and configurations.

\begin{tabular}{|c|c|}
\hline Category & Model setup \\
\hline Simulation period & January-December 2012 \\
\hline Domains & Europe, 161 x 131 grids \\
\hline Horizontal resolutions & $36 \mathrm{~km} \times 36 \mathrm{~km}$ \\
\hline Vertical resolution & 48 layers \\
\hline $\begin{array}{l}\text { Shortwave and longwave } \\
\text { radiation }\end{array}$ & RRTMG \\
\hline Land-surface model & Noah LSM \\
\hline Boundary layer scheme & YSU \\
\hline Cumulus parameterization & Grell and Denvenyi (2002) \\
\hline Microphysics & Lin et al. (1983) \\
\hline Chemistry & $\begin{array}{l}\text { RADM2\&MADE/SORGAM } \\
\text { with aqueous reactions }\end{array}$ \\
\hline
\end{tabular}

*Please refer to the WRF and the WRF-Chem user's guides for a complete description of the options. 
emissions variations (a description of the dynamic model is given in the following section). This simulation is in the following referred to as "DYNAMIC."

\section{Dynamic Emissions Model}

The fundamentals of the dynamic emissions model are provided by Gyldenkærne et al. [16], Skjøth et al. [50], and Skjøth et al. [18]. The model code is freely available and flexible for use with respect to geographical area and underlying assumptions [18]. The general idea behind the emissions model is to use the gridded annual total $\mathrm{NH}_{3}$ emissions (in this study the TNO MACC II [48]) and to use available activity data to make a disaggregation of the gridded annual totals into specific agricultural sectors. The emissions from each sector is then simulated with individual parametrizations. The TNO emissions was regridded to the WRF-Chem grid using a mass conservation approach. The emissions from each agricultural sector uses a parameterisation that depends on both the volatilisation as a function of meteorology and the temporal pattern of activity. The emissions are distributed differently thought the year, but the total emissions per grid cell are kept equal to the original emissions (TNO MACC II). The meteorological parameters used in the dynamic model, $2 \mathrm{~m}$ temperature and $10 \mathrm{~m}$ wind speed, were calculated with WRF-Chem with $1 \mathrm{~h}$ temporal resolution and with 36 $\mathrm{km}$ x $36 \mathrm{~km}$ spatial resolution. The emissions parameterization consists of 16 additive continuous functions, describing emissions from animal houses and storage (three functions), the application of manure and mineral fertilizer (seven functions), emissions from crops (four functions), grazing animals, and ammonia treatment of straw, respectively. The individual functions are distributed into two groups: Gaussian functions for short-term emissions sources and annual functions. Both groups respond to the environmental variables of wind speed and temperature. The Gaussian functions are linked to a crop growth model developed by Olesen and Plauborg [51]. The crop growth model uses accumulated temperature sums to determine the timing of the maximum value of the individual Gauss functions. The applied functions were originally derived for Danish conditions and presented in Skjøth et al. [50], but Skjøth et al. [18] suggest that a majority of the functions may be directly applicable for a large part of Europe. Default values were therefore implemented by Skjøth et al. [18] for many European countries.

Several of the underlying studies for producing parameterizations, such as the applied growth model [51] and the farm surveys by Seedorf et al. [52-53]standard deviation, minimum and maximum values of dry bulb air temperature and relative humidity $\mathrm{RH}$, are based on European-wide studies and are considered appropriate for large geographical regions [18]. In this European-wide implementation, the predicted peak time of each of the Gaussian functions (as simulated by the crop growth model) is allowed to vary two months from south to north. This ensures that spring applications of manure and mineral fertilizer will happen during spring, even if the meteorologi- cal data set predicts a specific area to be particularly cold or warm (e.g., a very warm and dry spring, which would make agricultural operations sensible already in January). This ensures that the model fits reasonably well for most European regulations. The earliest peak time follows manure/slurry application on black soil (10 March), mineral fertilizer on black soil (20 March), manure/slurry application in growing crops (15 April), and manure/slurry application as well as mineral fertilizer on grassland (15 July).

Some countries such as the Netherlands allow for some application of husbandry manure into specific soils and crops already after 1 February. Depending on the size of storage facilities, national regulations and the progress of the previous autumn/winter, this can force farmers in specific areas to apply a fraction of their manure as soon as possible because their storage facilities are full. These specific regulations for countries are not included in the dynamic model.

\section{Model Evaluation}

The focus in this study is on improved understanding of short-term variations of ammonia and the impact from agricultural emissions sources as well as evaluating the WRF-Chem model capabilities in simulating ammonia concentrations across Europe. We used all available EMEP-EBAS (ebas.nilu.no) stations with hourly, daily, and monthly (here also one-week, two-week, and threeday observations were taken) resolution of ammonia concentrations and all hourly Dutch stations available through the RIVM web page (www.rivm.nl) for 2012. The data set comprised 32 stations in total (13 of them measuring hourly concentrations). The statistics between the models and observations were calculated for three temporal resolutions: one hour, one day, and one month. In the case of daily values all daily stations were used and additionally all hourly aggregated daily. In the case of monthly evaluations all stations were used and the results from stations with higher than monthly resolution were aggregated monthly. Additionally, the stations were divided into two groups with respect to the ammonia emission: for each station we calculated a buffer with a diameter of $2 \mathrm{~km}$ and then checked the dominant land use according to Corine Land Cover 2006 (CLC). If the prevailing land use was agricultural then the station was classified as "agricultural." When another type of land use was dominant the station was treated as "non-agricultural." This division was used for calculating statistics and plotting time series.

For a more complete evaluation of the WRF-Chem model results we have also compared modelled aerosol concentrations $\left(\mathrm{NH}_{4}+, \mathrm{NO}_{3}^{-}\right.$, and $\left.\mathrm{SO}_{4}^{2-}\right)$ with daily EMEPEBAS observations. This included 24, 17, and 36 stations, respectively, for $\mathrm{NH}_{4}+, \mathrm{NO}_{3}-$, and $\mathrm{SO}_{4}{ }^{2-}$. The observations were compared with modelled hourly concentrations of aerosols aggregated to mean daily values. All the stations used in the evaluation process are presented in the supplementary materials (Fig. 1S).

Most of the daily and monthly $\mathrm{NH}_{3}$ and $\mathrm{NH}_{4}^{+}$ambient air concentrations were measured using the filter pack 


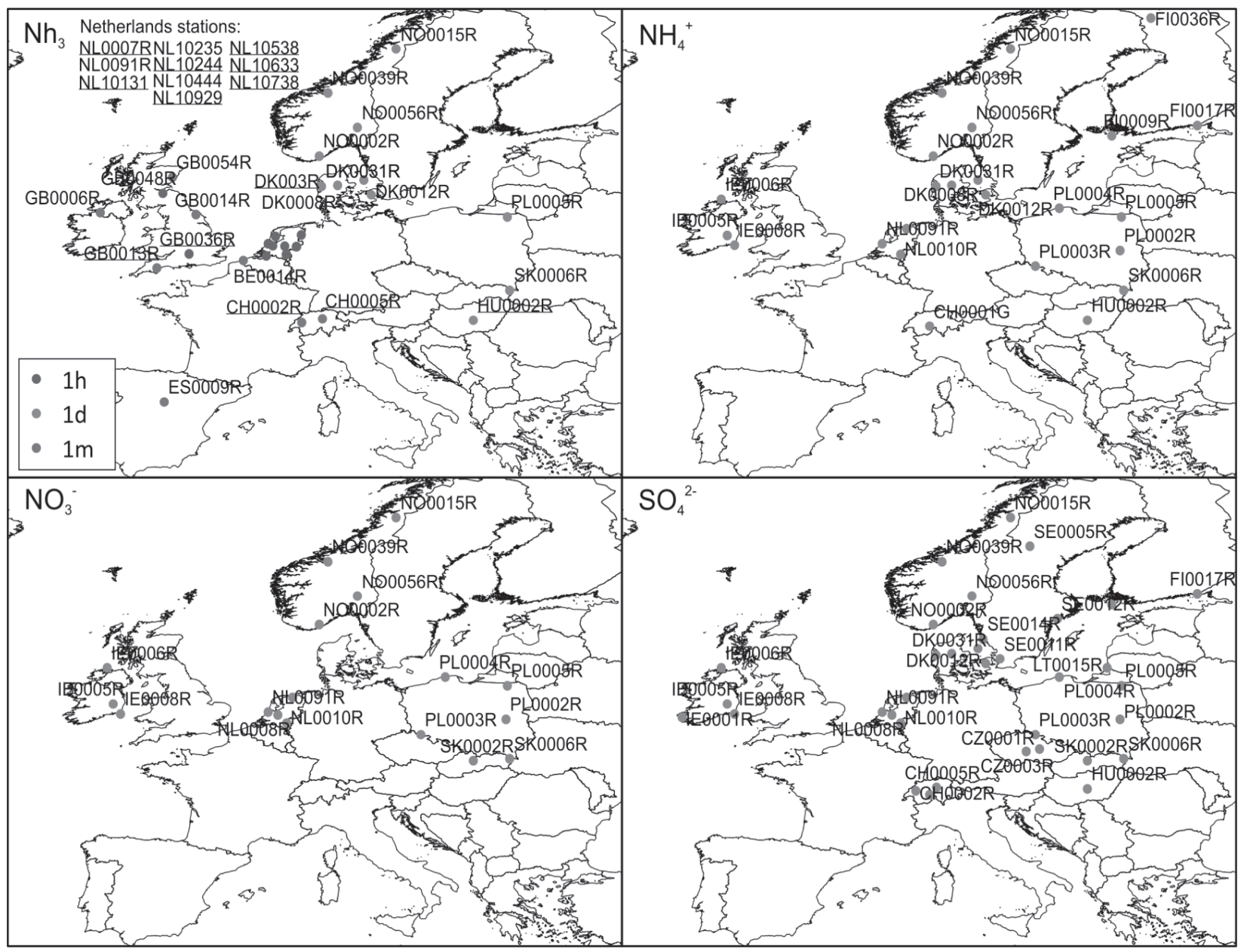

Fig. 1S. Locations of sites used in the model evaluation ( $1 \mathrm{~h}$ - hourly, $1 \mathrm{~d}$ - daily, $1 \mathrm{~m}$ - monthly temporal resolution). Ammonia stations classified as agricultural are underlined.

method, and some of the stations used the denuder method. The filter pack method does not give a complete separation of $\mathrm{NH}_{3}$ and $\mathrm{NH}_{4}$ [50]. However, comparisons between filter pack and denuder sampling have demonstrated that for Danish monitoring stations a satisfactory separation can be obtained [54].

In the model evaluation process, firstly we compared ammonia concentrations from the WRF-Chem model with measurements in hourly, daily and monthly temporal resolution. The seasons were calculated as follows: winter (January, February and December), spring (March, April and May), summer (June, July and August) and autumn (September, October and November). In the second step we calculated statistics in the same way, but only for stations located in agricultural areas. The stations were selected according to the method describe in the paragraph above.

For aerosols the statistics were calculated based on daily observations and individually for four seasons. Additionally, Taylor diagrams were prepared for both ammonia and aerosols, using all available stations for each chemical species (Taylor 2001). The diagram shows the results separately for the BASE and DYNAMIC simulation.
The following measurements were used to summarize the WRF-Chem model performance for ammonia and aerosols for both runs: factor of two (FAC2), mean bias (MB), normalized mean gross error (NMGE), and correlation coefficient $(\mathrm{R})$. The number of observations available for each season is listed in Tables 2, 3, 4, 5, and 6 as "N." Finally, we evaluated the spatial pattern in ammonia emissions by calculating the day of the year (Julian Day) for which the model estimated the highest hourly ammonia concentrations, with calculations performed independently for each grid cell. This was qualitatively compared against a similar figure obtained by satellite observations for 2013 .

\section{Results}

The results are presented in the following order: 1) temporal pattern of ammonia emissions and concentrations, including vertical distribution of concentrations; 2) spatial distribution of $\mathrm{NH}_{3}$ concentrations for the BASE and DYNAMIC simulations; and 3) comparisons of WRF-Chem ammonia and aerosol concentrations with observations for both the BASE and DYNAMIC runs. 


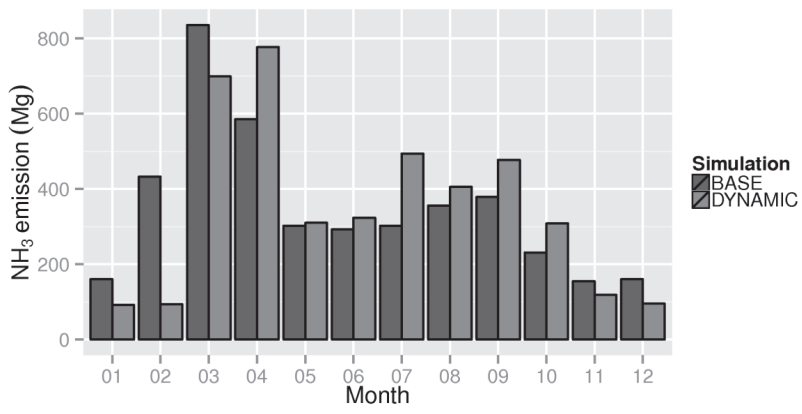

Fig. 1. Monthly distribution of ammonia emissions (sums for all grid cells) for the BASE and DYNAMIC approaches.

\section{Ammonia Emissions and Concentrations}

The mean monthly pattern for all grid cells for the BASE and DYNAMIC emissions is given in Fig. 1. The greatest difference between the monthly sums is in winter (January and February), when the DYNAMIC emissions gives much lower sums, up to 4.5 times in February, than the BASE emissions. There is a shift in the spring time peak of emissions (up to 30\%) as the BASE emissions give higher values in March and DYNAMIC in April. The DYNAMIC approach gives higher values between July and October. This temporal pattern is also reflected in both modelled and observed monthly ammonia concentrations (Fig. 2). For most stations the DYNAMIC approach gives higher concentrations in late summer and in autumn, and the modelled values are closer to observations if compared to the BASE run. The spring peak differs between stations and for some geographical locations, e.g., at Great Britain stations DYNAMIC gives a higher peak than BASE in March. However, for other locations, e.g., at stations in the Netherlands, the concentrations from the BASE simulation are higher.

The hourly profiles of ammonia emissions (DYNAMIC approach only) and modelled and measured concentrations (both BASE and DYNAMIC) are shown for Harwell station (UK, GB 0036R), which is located in an agricultural area. These profiles are calculated for each of the four seasons and then normalised for this comparison (Fig. 3). The dynamic approach shows that the emissions typically peak during the afternoon in each case, starting from 13:00 in the autumn to 15:00 in the winter, and that the minimum is around 06:00 in the morning, where the difference is up to a factor of two between minimum and maximum. According to the observed values, the highest $\mathrm{NH}_{3}$ concentrations are during the day, between 09:00 and 15:00. Modelled concentration peaks are shifted toward afternoon hours when compared with measured $\mathrm{NH}_{3}$ concentrations. The lowest concentrations are modelled at midday and the highest at night. This pattern is similar for all the seasons considered. For each season, the DYNAMIC pattern is slightly closer to measurements than BASE, but both simulations fail to reflect the midday peak of $\mathrm{NH}_{3}$ concentrations. The closest agreement between the measurements and the DYNAMIC run is for winter. For this season, there is also the largest improvement if the BASE and DYNAMIC runs are compared, but for both runs the peak in $\mathrm{NH}_{3}$ concentration is shifted toward
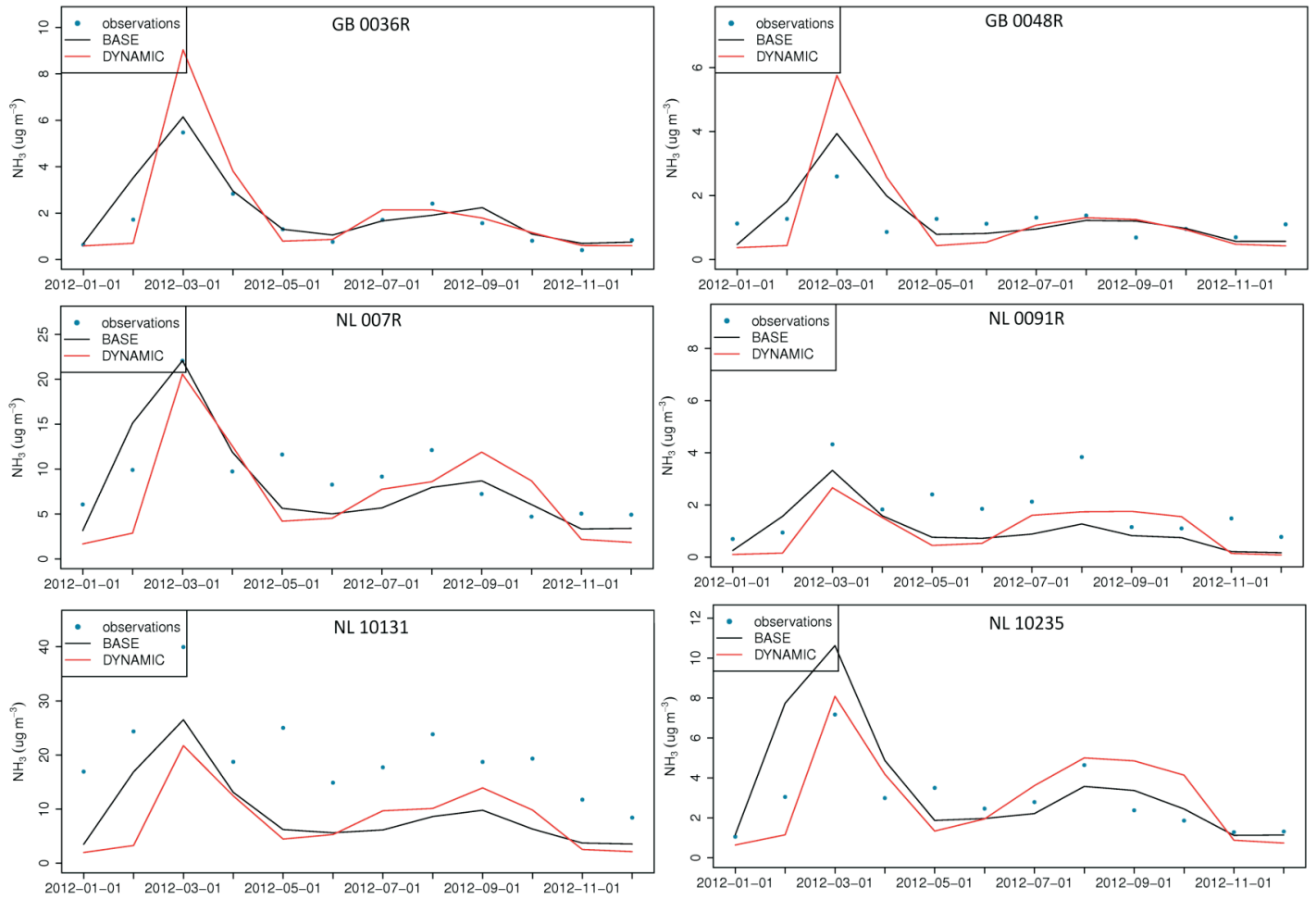

Fig. 2. Mean monthly concentrations of ammonia for selected agricultural (left column) and non-agricultural (right column) sites. 

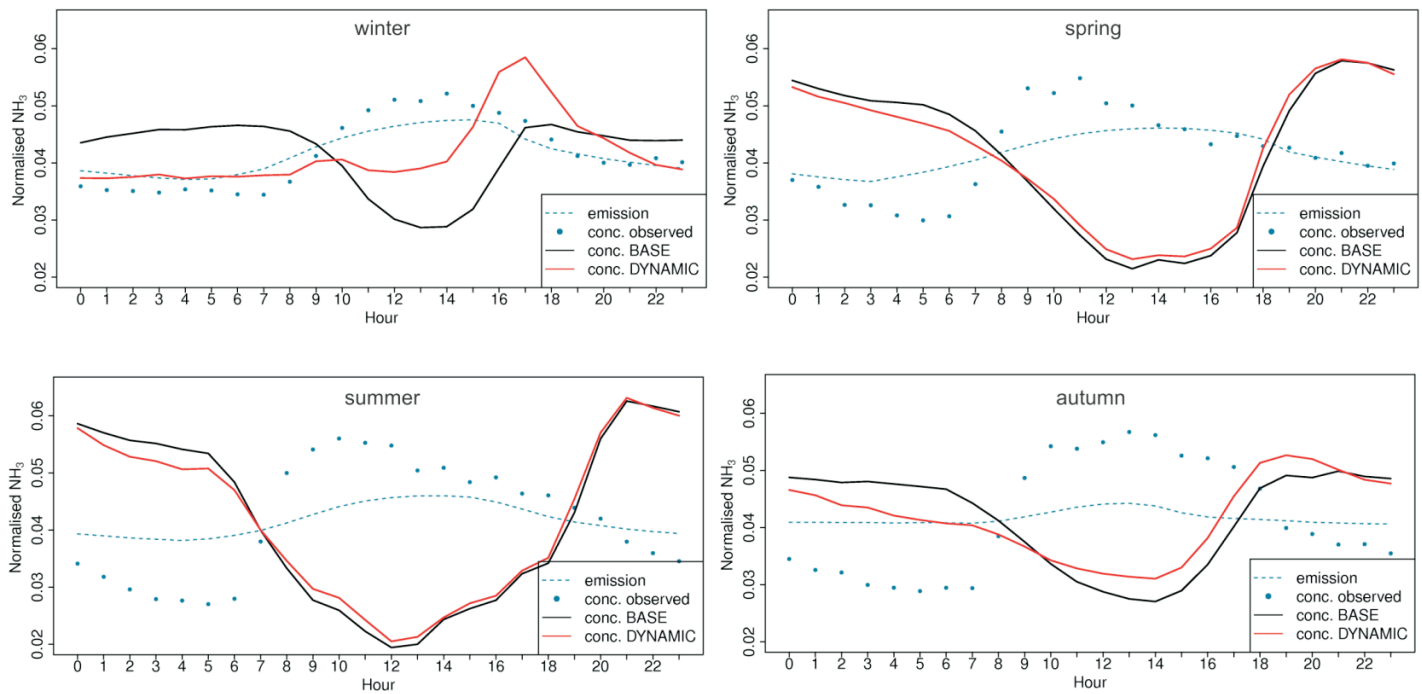

Fig. 3. Normalized $\mathrm{NH}_{3}$ concentrations and emissions according to hours for four seasons for the grid corresponding to Harwell Station. Normalization procedure: the sum of emissions/concentrations for each individual hour (0-23) was divided by the total sum of emissions/ concentrations in the season.

the afternoon hours. The hourly profiles of ammonia concentrations for other sites are similar as described above and the midday peak present in the measurements is not represented by the measurements (Fig. 4).

The modelled and measured hourly time series of ammonia concentrations are presented in Fig. 5. The modelled peak of ammonia concentrations starts at the beginning of February for the BASE simulation and is moved toward March and April for the DYNAMIC simulation. The spring peak is much more extended in time in the BASE simulation, if compared to DYNAMIC. Therefore, BASE overestimates measured concentrations
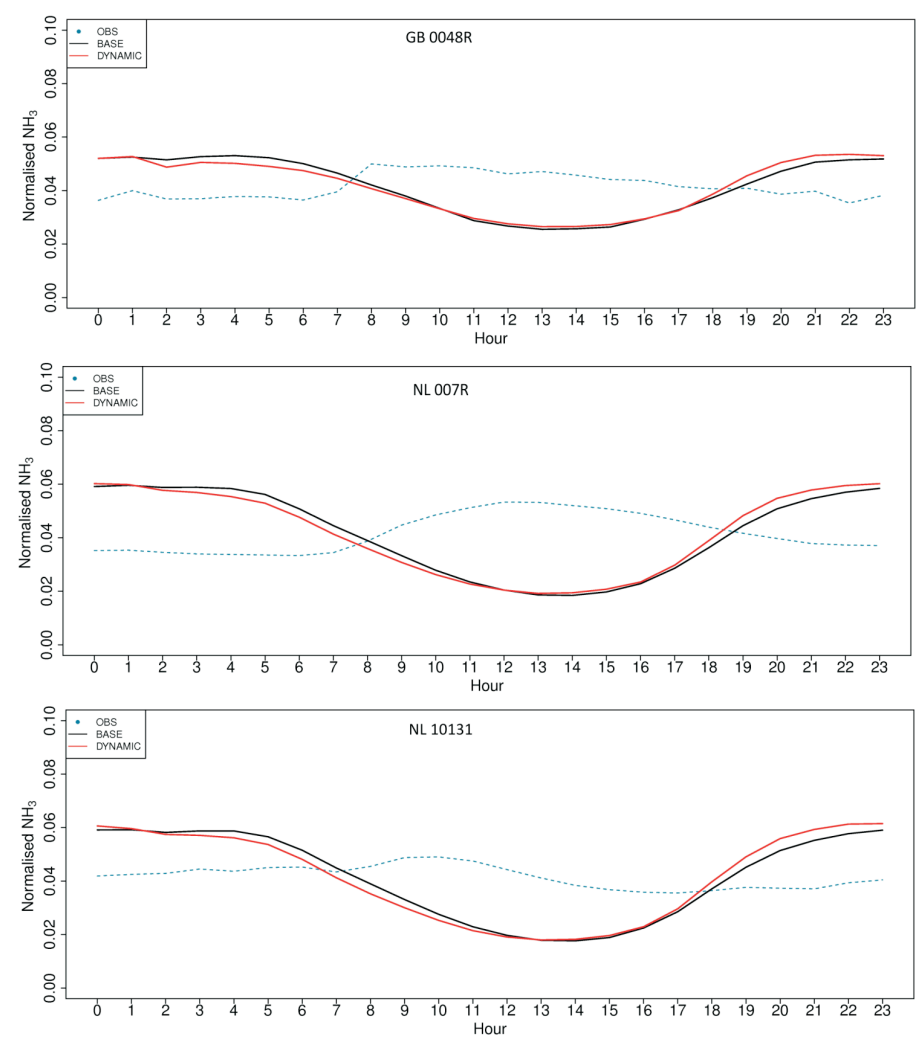

Fig. 4. Normalized $\mathrm{NH}_{3}$ concentrations (modelled and measured) according to hours, corresponding to the measurement stations. Normalization procedure: the concentration for each individual hour (0-23) was divided by the total concentration in 2012. 
at the beginning of February at some stations (e.g., GB0036R, NL007R, and NL10235). At the agricultural stations (NL007R, NL10131) both models underestimate $\mathrm{NH}_{3}$ concentrations in late autumn and early winter (November and December). For the stations located in the area close to ammonia sources and with very high measured concentrations (e.g., NL10131, above $50 \mu \mathrm{g} \mathrm{m}^{-3}$ ) both models underestimate observations throughout the year. For non-agricultural stations (e.g., NL0091R), the DYNAMIC simulation is able to capture many individual peaks (e.g., in March, July, and August), but the concentrations in November and December are underestimated.

The vertical distribution of $\mathrm{NH}_{3}$ concentrations has been presented at Harwell Station (UK) for the selected periods of 1-7 of February, April, July, and October 2012 using WRF-Chem. The vertical distribution of ammonia for the BASE and DYNAMIC simulation is similar for all seasons (Figs 6 and 2S). The general pattern indicates that the highest concentrations are at the surface layer with a linear decrease toward the upper layers. The WRF-Chem model calculates the highest ammonia concentrations at night, with the time of the maximum varying according to the month. During the periods analysed, this usually occurs before or at midnight in February and July, and after or at midnight in April. In October, the maximum values appear both before and after midnight. In July and October there are individual days with increased concentrations in the upper layers (4 July and 5 October) and that are accompanied by high surface concentrations. The daily pattern of the ammonia concentration is seen to be less regular for some short periods - e.g., on 5 April, which is related to a precipitation event during that day and washout of ammonia from the atmosphere. For all episodes, ammonia concentration peaks are negatively correlated with PBL height (not presented in the figure). In fact, the periods with the strongest diurnal pattern of ammonia concentrations are also on the days with large differences in PBLH between day and night. For April, we have illustrated the vertical distribution of $\mathrm{NO}_{3}^{-}, \mathrm{NH}_{4}^{+}$, and $\mathrm{SO}_{4}^{2-}$ concentrations in the supplementary material (Fig. 3S). It can be seen that high concentrations of airborne aerosols are slightly shifted with a later peak compared to the peak values of ammonia concentrations (aerosol peaks are about 1-2 h later). These figures also show that the maximum aerosol concentrations appear above the surface layer; for $\mathrm{NO}_{3}{ }^{-}$and $\mathrm{NH}_{4}^{+}$this is usually about $200 \mathrm{~m}$ above ground level.

The qualitative comparison of modelled results (Fig. 4S) with a satellite product from Van Damme et al.
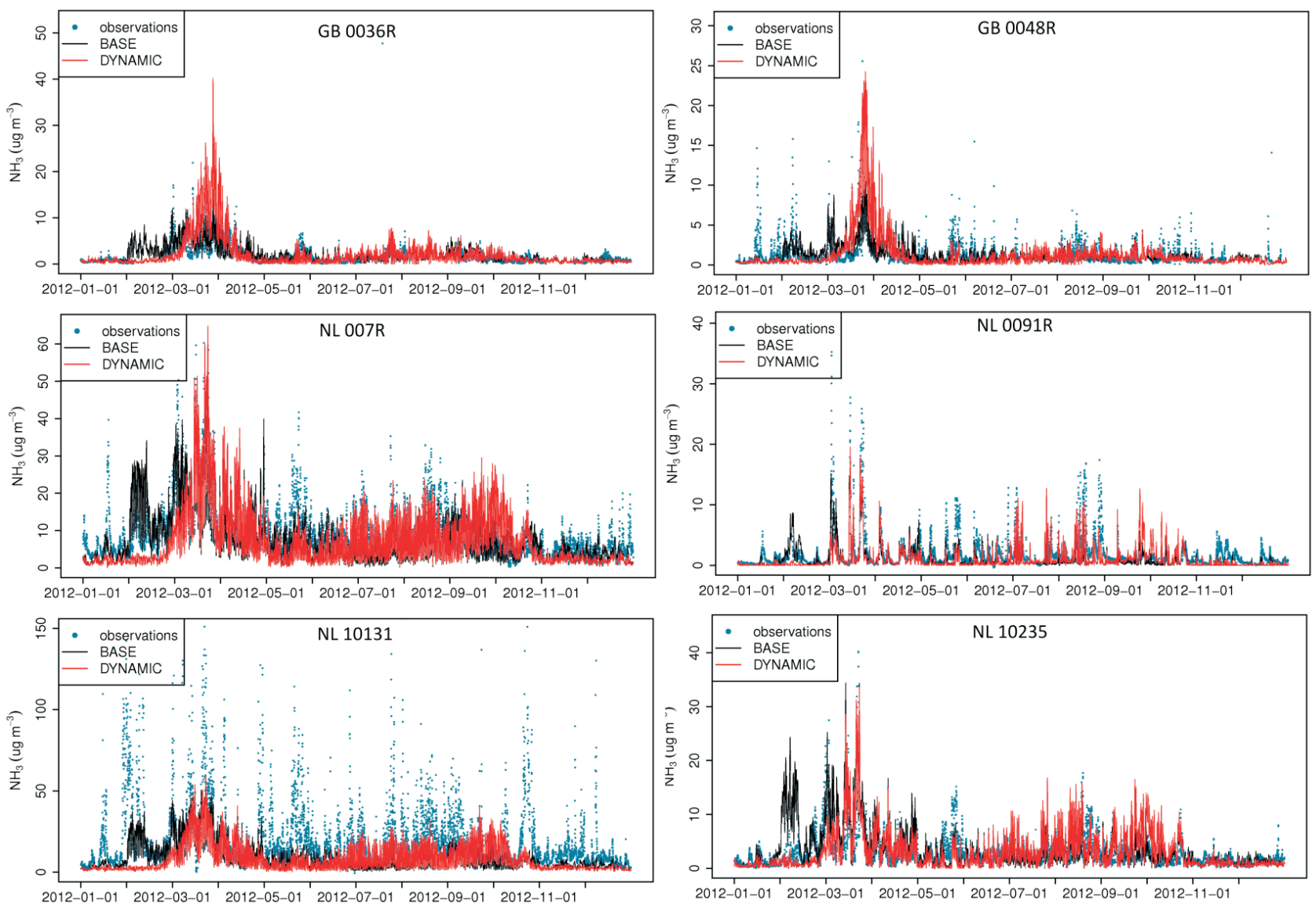

Fig. 5. Hourly ammonia concentrations for the selected agricultural (left column) and non-agricultural (right column) sites. Please notice the differences in y axes. 

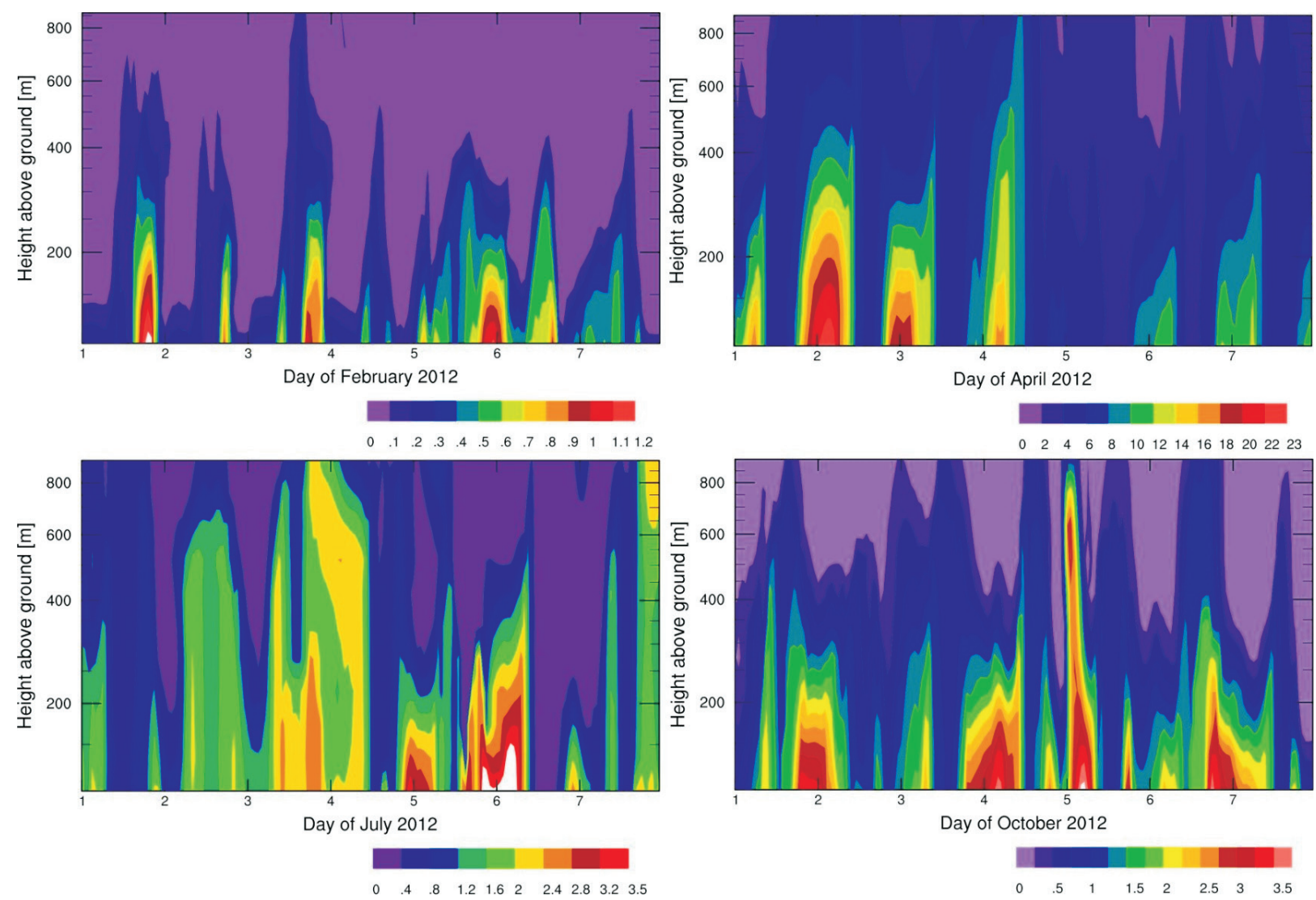

Fig. 6. Temporal and vertical distribution of $\mathrm{NH}_{3}$ concentrations $\left[\mu \mathrm{g} \mathrm{m}^{-3}\right]$ for the DYNAMIC scenario for the grid corresponding to Harwell Station.

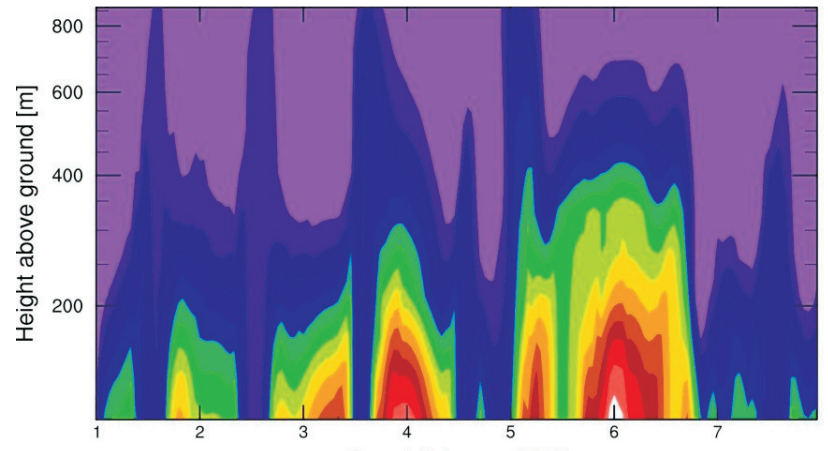

Day of February 2012

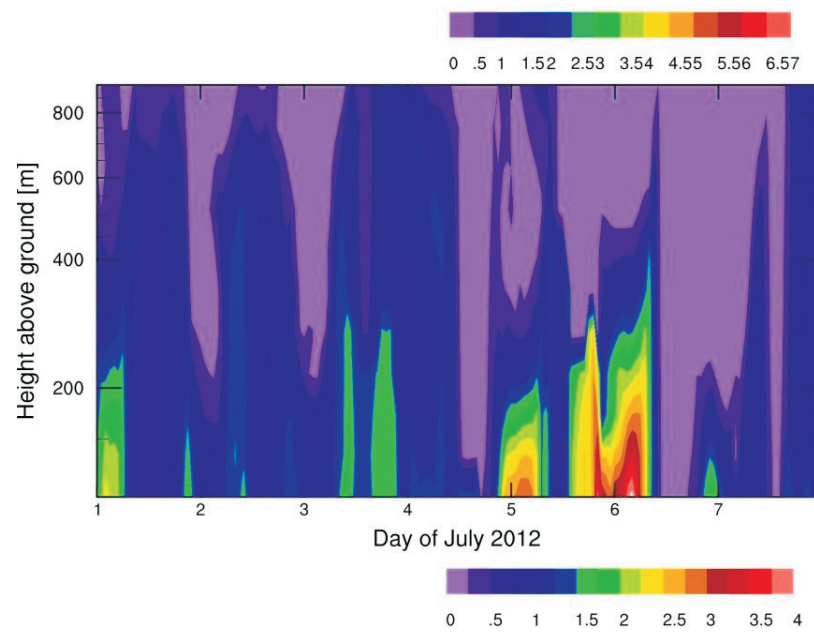

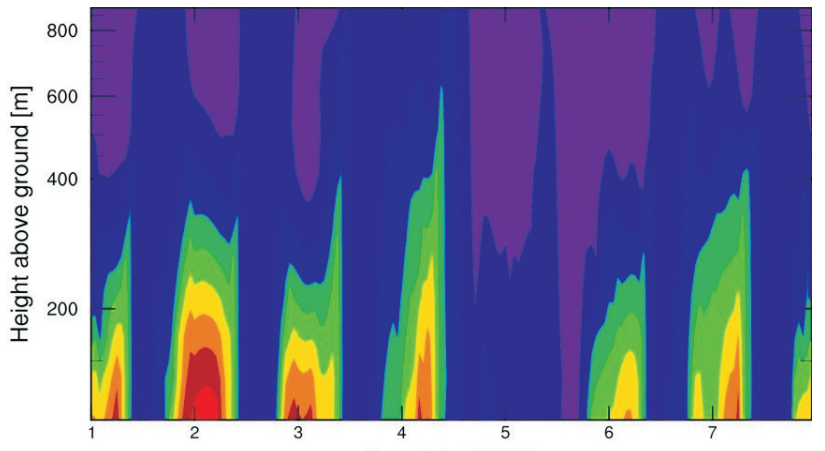

Day of April 2012

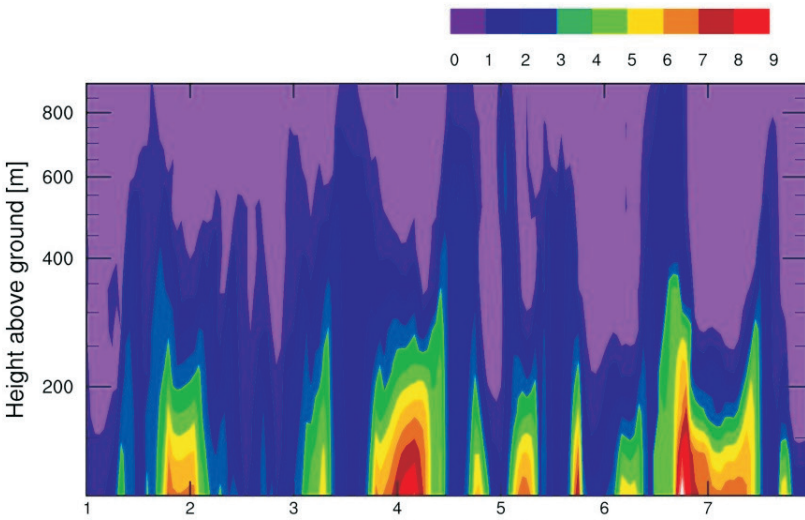

Day of October 2012

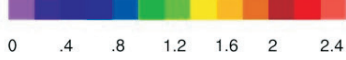

Fig. 2S. Temporal and vertical distributions of $\mathrm{NH}_{3}$ concentrations $\left(\mu \mathrm{g} \mathrm{m}^{-3}\right)$ for the BASE scenario. 
$\mathrm{NO}_{3}$

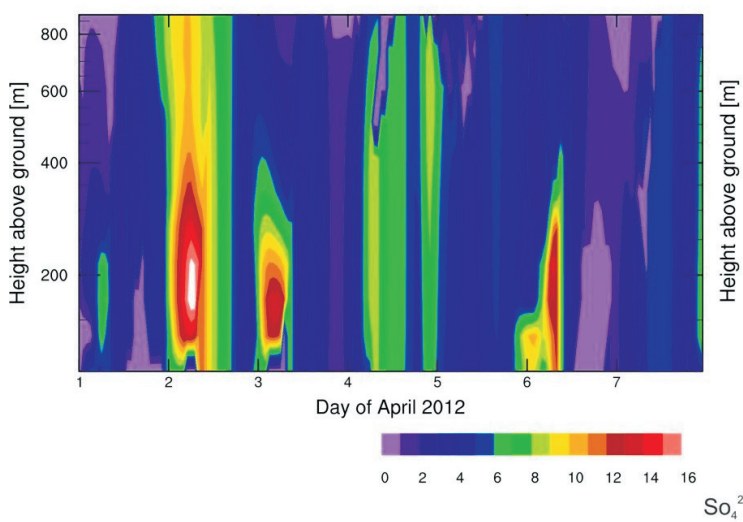

$\mathrm{So}_{4}$
$\mathrm{Nh}_{4}$
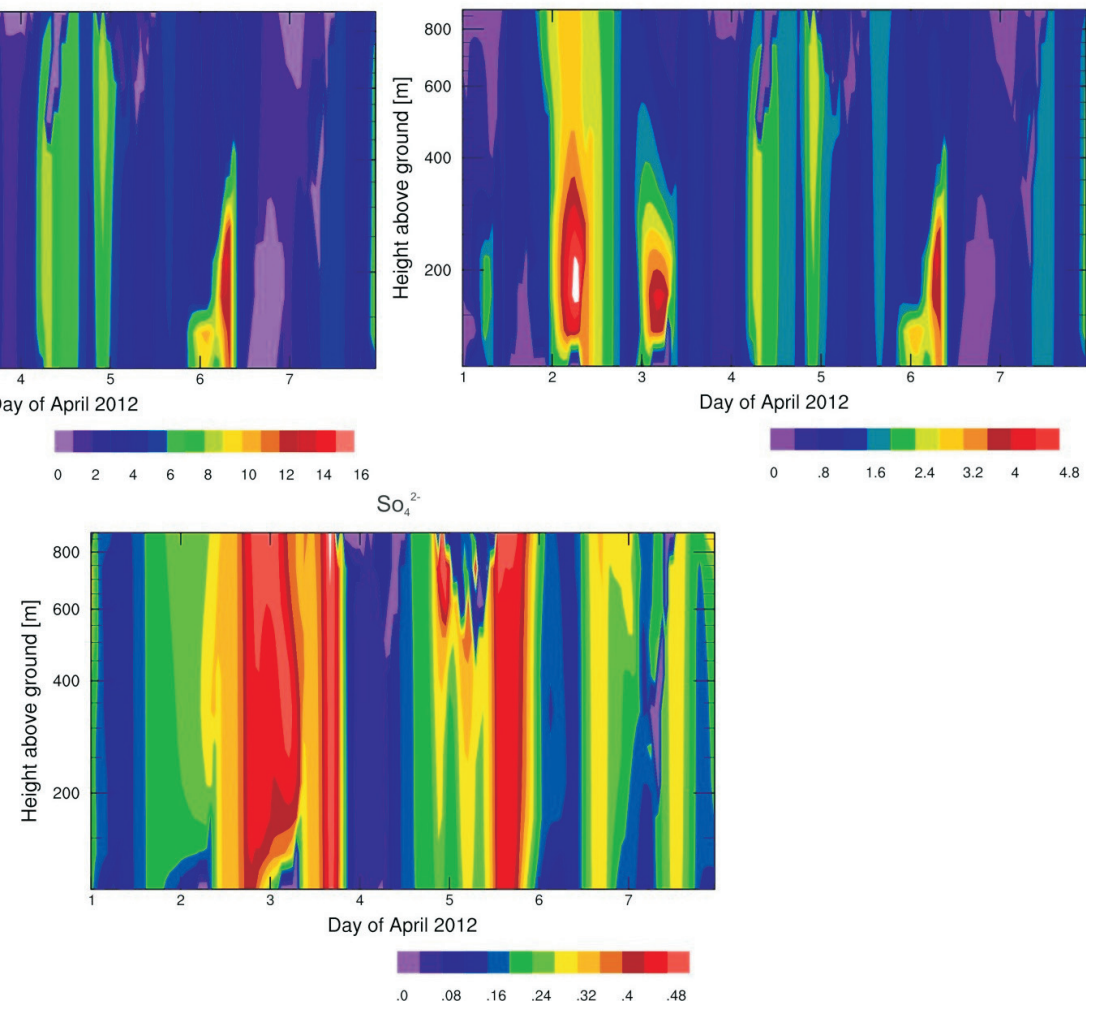

Fig. 3S. Temporal and vertical distribution of aerosol concentrations $\left(\mu \mathrm{g} \mathrm{m}^{-3}\right)$ for the DYNAMIC scenario for the April episode.
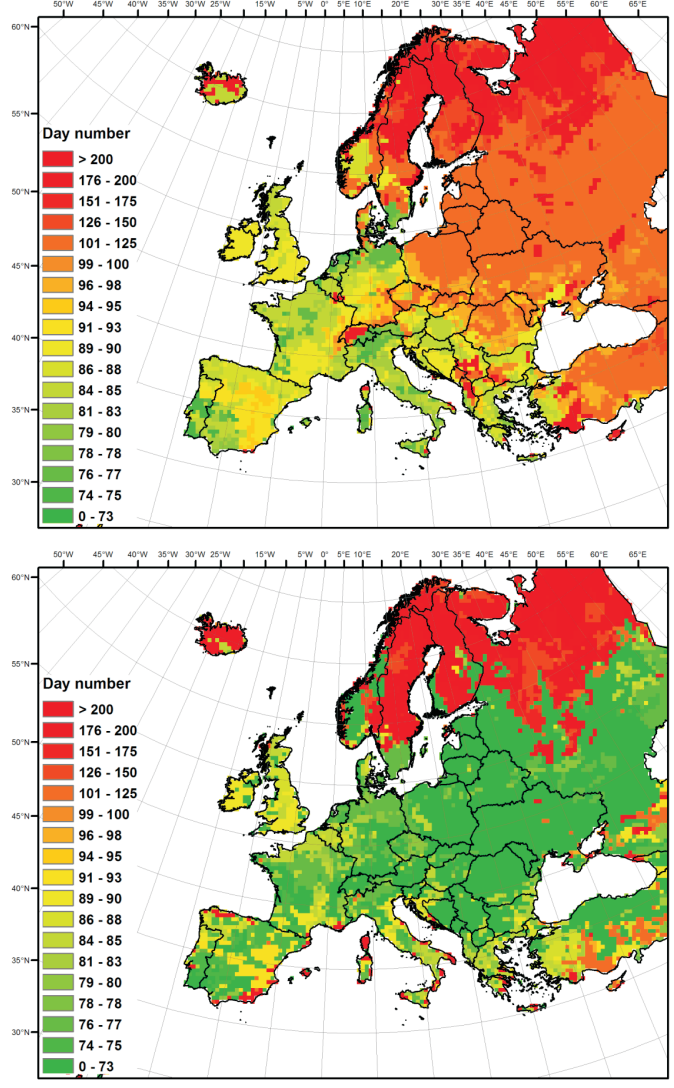

Fig. 4S. Julian day number in the year 2012, for which the model calculated the highest hourly ammonia concentrations (upper figure for the DYNAMIC and lower for the BASE simulations).
[55] shows a similar pattern over a large geographical area from Central France and the Alps in the south to Denmark and parts of the United Kingdom in the north. Parts of the United Kingdom and Scandinavia do not contain data in van Damme et al. [56]. In this large geographical area the peak concentrations are observed to be from March to May with a tendency to a delayed peak in the more northern parts. In Spain and Portugal, the picture is much more diverse. Many areas have their peak concentrations in March-May, while neighbouring areas peak during summer. This summer peak concentration is not observed in the model calculation. A similar picture is seen for Italy, where the peak concentration is in March-May over the Po Valley but generally in summer in the rest of Italy. Only the Po Valley is well reproduced here by the model, while the summer peak is not reproduced. Over the Balkan region and the Pannonian Plain, the peak concentrations are observed to happen during summer, while the simulation peaks are during spring. In France, the picture is also diverse. The majority of the country has a peak during March-May, while the southwestern parts contain a large area where the peak concentration is in the middle of the summer. This is not reproduced by the model.

\section{Model Evaluation for the BASE and DYNAMIC Simulation for $\mathrm{NH}_{3}$ and Aerosols $\left(\mathrm{NH}_{4}^{+}, \mathrm{NO}_{3}^{-}, \mathrm{SO}_{4}^{2-}\right)$}

A comparison of modelled and measured hourly, daily, and monthly $\mathrm{NH}_{3}$ concentrations for all stations is 


\begin{tabular}{|c|c|c|c|c|c|c|c|c|c|c|c|}
\hline \multirow{5}{*}{ 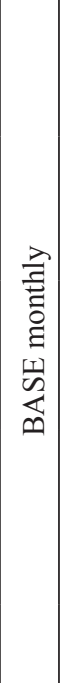 } & $\simeq$ & $\begin{array}{l}\vec{b} \\
: \\
0\end{array}$ & 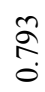 & $\begin{array}{c}\hat{\hat{d}} \\
0 \\
0\end{array}$ & $\begin{array}{l}\tilde{\alpha} \\
\stackrel{0}{6}\end{array}$ & \multirow{5}{*}{ 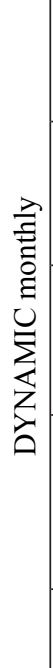 } & $\simeq$ & $\begin{array}{l}\hat{\delta} \\
\stackrel{0}{0}\end{array}$ & $\begin{array}{l}n \\
\stackrel{n}{0} \\
0\end{array}$ & $\begin{array}{l}\stackrel{2}{\circ} \\
0\end{array}$ & $\frac{⿱}{t}$ \\
\hline & $\sum_{z}^{1}$ & $\begin{array}{l}\widehat{\lambda} \\
\infty \\
0 \\
0\end{array}$ & 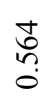 & 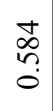 & 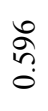 & & $\sum_{\bar{Z}}^{\sqrt[n]{0}}$ & $\begin{array}{l}\vec{b} \\
\stackrel{0}{0}\end{array}$ & $\begin{array}{l}0 \\
0 \\
0 \\
0\end{array}$ & 命 & $\begin{array}{l}\hat{3} \\
0 \\
0\end{array}$ \\
\hline & $\stackrel{m}{\Sigma}$ & $\begin{array}{l}\overrightarrow{0} \\
\tilde{0}\end{array}$ & $\begin{array}{l}\text { సิ } \\
\text { ô }\end{array}$ & $\begin{array}{l}8 \\
\stackrel{8}{0} \\
-i\end{array}$ & $\begin{array}{l}\hat{n} \\
\stackrel{0}{i}\end{array}$ & & $\stackrel{p}{\Sigma}$ & $\begin{array}{c}\vec{b} \\
\stackrel{+}{1} \\
\end{array}$ & $\begin{array}{l}\stackrel{0}{0} \\
\stackrel{0}{i}\end{array}$ & 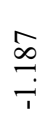 & $\frac{\stackrel{\infty}{+}}{\stackrel{+}{i}}$ \\
\hline & 莡 & 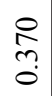 & तิ & 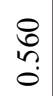 & ঙ̆ & & 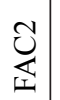 & 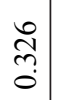 & 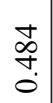 & $\begin{array}{l}\infty \\
\stackrel{n}{n} \\
?\end{array}$ & $\stackrel{\text { fon }}{\stackrel{0}{0}}$ \\
\hline & Z & สু & $\bar{a}$ & $\bar{\sigma}$ & $\bar{\sigma}$ & & z & $\sigma$ & $\bar{\sigma}$ & ন & $\bar{\sigma}$ \\
\hline \multirow{5}{*}{ 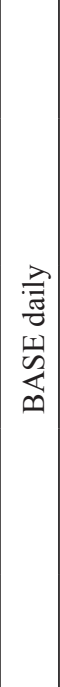 } & $\simeq$ & 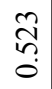 & $\begin{array}{l}+ \\
0 \\
0\end{array}$ & 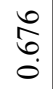 & $\begin{array}{l}\text { fै } \\
\stackrel{0}{0}\end{array}$ & \multirow{5}{*}{ 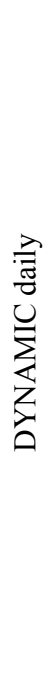 } & $\simeq$ & $\begin{array}{l}\infty \\
\tilde{n} \\
0\end{array}$ & $\begin{array}{l}0 \\
\text { ర్ర } \\
0\end{array}$ & $\begin{array}{l}\text { : } \\
\stackrel{0}{0}\end{array}$ & 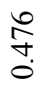 \\
\hline & $\sum_{\mathrm{Z}}^{\mathrm{N}}$ & $\begin{array}{l}\begin{array}{r} \pm \\
\infty \\
0 \\
0\end{array}\end{array}$ & $\begin{array}{l}\bar{\infty} \\
\overbrace{0}\end{array}$ & $\begin{array}{l}\overrightarrow{\widetilde{\sigma}} \\
\stackrel{0}{0}\end{array}$ & $\begin{array}{l}\stackrel{t}{t} \\
\stackrel{0}{0}\end{array}$ & & $\sum_{\bar{Z}}^{\sqrt[n]{0}}$ & $\begin{array}{l}\hat{R} \\
\stackrel{\hat{R}}{0}\end{array}$ & \begin{tabular}{l}
$\mathbb{Z}$ \\
\multirow{d}{0}{} \\
0
\end{tabular} & $\frac{+}{n}$ & $\stackrel{\frac{n}{n}}{\frac{0}{0}}$ \\
\hline & $\sum_{\Sigma}^{m}$ & $\begin{array}{l}2 \\
o \\
\dot{q} \\
\dot{i}\end{array}$ & 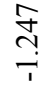 & $\begin{array}{l}0 \\
b \\
i \\
i\end{array}$ & $\stackrel{\infty}{m} \underset{?}{\longrightarrow}$ & & $\stackrel{m}{\Sigma}$ & $\begin{array}{c}\mathcal{Y} \\
\stackrel{T}{T}\end{array}$ & $\begin{array}{l}\stackrel{2}{2} \\
\stackrel{1}{1}\end{array}$ & $\begin{array}{l}\underset{\text { त̂}}{i} \\
\stackrel{i}{i}\end{array}$ & 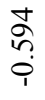 \\
\hline & 导 & 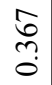 & $\stackrel{\bar{q}}{\circ}$ & $\begin{array}{l}5 \\
\vdots \\
0 \\
0\end{array}$ & 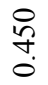 & & 式 & $\begin{array}{l}\infty \\
\stackrel{\infty}{ } \\
\stackrel{0}{0}\end{array}$ & $\begin{array}{l}8 \\
\text { b } \\
0 \\
0\end{array}$ & 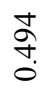 & बे \\
\hline & z & $\underset{\mathscr{D}}{\mathscr{\alpha}}$ & $\stackrel{\bar{n}}{\Omega}$ & $\begin{array}{l}\overrightarrow{0} \\
\infty \\
-\rightarrow\end{array}$ & \begin{tabular}{l}
0 \\
\multirow{1}{0}{} \\
- \\
-
\end{tabular} & & $\mathrm{z}$ & $\begin{array}{l}\widehat{\sigma} \\
\text { ô } \\
-\end{array}$ & $\vec{\sigma}$ & 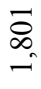 & 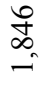 \\
\hline \multirow{5}{*}{ 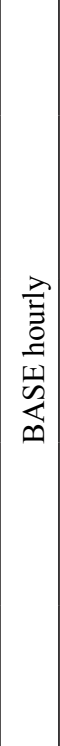 } & $\simeq$ & ڤ్ & $\stackrel{\vartheta}{\vec{f}}$ & 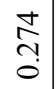 & 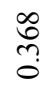 & \multirow{5}{*}{ 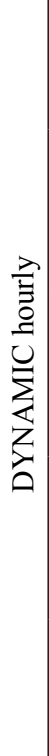 } & $\simeq$ & $\begin{array}{l}\tilde{B} \\
\tilde{0} \\
0\end{array}$ & $\begin{array}{l}\hat{\infty} \\
\tilde{0} \\
\vdots\end{array}$ & $\frac{\pi}{3}$ & 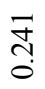 \\
\hline & $\sum_{\bar{Z}}^{\sqrt{n}}$ & 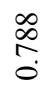 & 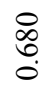 & $\begin{array}{l}\stackrel{\infty}{\gtrless} \\
\stackrel{0}{0}\end{array}$ & $\begin{array}{l}\widehat{\infty} \\
0 \\
0\end{array}$ & & $\sum_{\bar{Z}}^{\sqrt[n]{0}}$ & $\begin{array}{l}\stackrel{n}{\hat{\imath}} \\
\stackrel{0}{0}\end{array}$ & $\begin{array}{l}\stackrel{2}{?} \\
\vdots\end{array}$ & $\begin{array}{l}\hat{\hat{o}} \\
\stackrel{0}{0}\end{array}$ & $\begin{array}{l}\text { त̂ } \\
\infty \\
\stackrel{0}{0}\end{array}$ \\
\hline & $\stackrel{\eta}{\Sigma}$ & 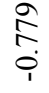 & $\begin{array}{l}\vec{D} \\
\stackrel{\oplus}{r}\end{array}$ & $\begin{array}{l}n \\
\vdots \\
\dot{b} \\
\dot{r} \\
r\end{array}$ & $\begin{array}{l}\overrightarrow{0} \\
i \\
i\end{array}$ & & $\stackrel{m}{\Sigma}$ & 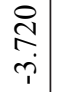 & $\begin{array}{l}\tilde{N} \\
\stackrel{y}{+} \\
+\end{array}$ & $\begin{array}{l}\overrightarrow{0} \\
\stackrel{f}{i}\end{array}$ & $\underset{\mathrm{f}}{\mathrm{f}}$ \\
\hline & ঠֶ & $\underset{f}{\exists}$ & 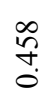 & $\begin{array}{l}\infty \\
\tilde{c} \\
\tilde{0}\end{array}$ & 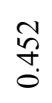 & & $\begin{array}{l}\tilde{\mathbb{I}} \\
\mathbb{1}\end{array}$ & $\underset{\overbrace{}}{\tilde{0}}$ & $\underset{\vec{\partial}}{\dot{\partial}}$ & $\begin{array}{l}\vec{\infty} \\
\stackrel{\overbrace{}}{0}\end{array}$ & 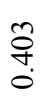 \\
\hline & z & 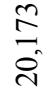 & 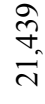 & 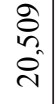 & $\begin{array}{l}\text { ठे } \\
\text { ते }\end{array}$ & & $z$ & $\begin{array}{l}\stackrel{2}{\Xi} \\
\stackrel{\sim}{n}\end{array}$ & 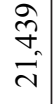 & $\begin{array}{l}\text { के } \\
\text { है } \\
\text { ते }\end{array}$ & $\begin{array}{l}\text { ㅁ. } \\
\text { ¿े }\end{array}$ \\
\hline & 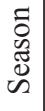 & 离 & 咢考 & 离 & $\begin{array}{l}\text { 童 } \\
\text { 言 }\end{array}$ & & $\begin{array}{c}\tilde{0} \\
\tilde{d} \\
\tilde{D} \\
\omega\end{array}$ & 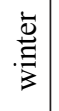 & 点竞 & 离 & $\begin{array}{l}\text { 詰 } \\
\text { 言 }\end{array}$ \\
\hline
\end{tabular}

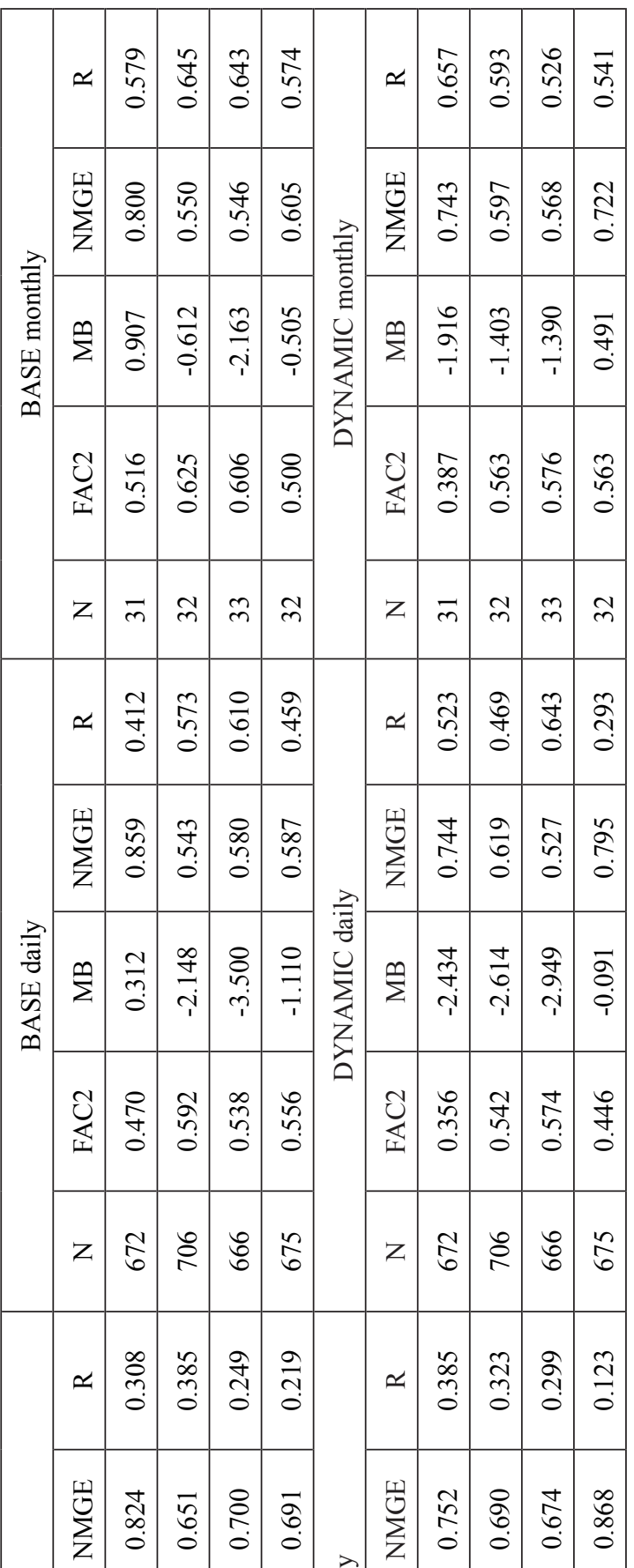

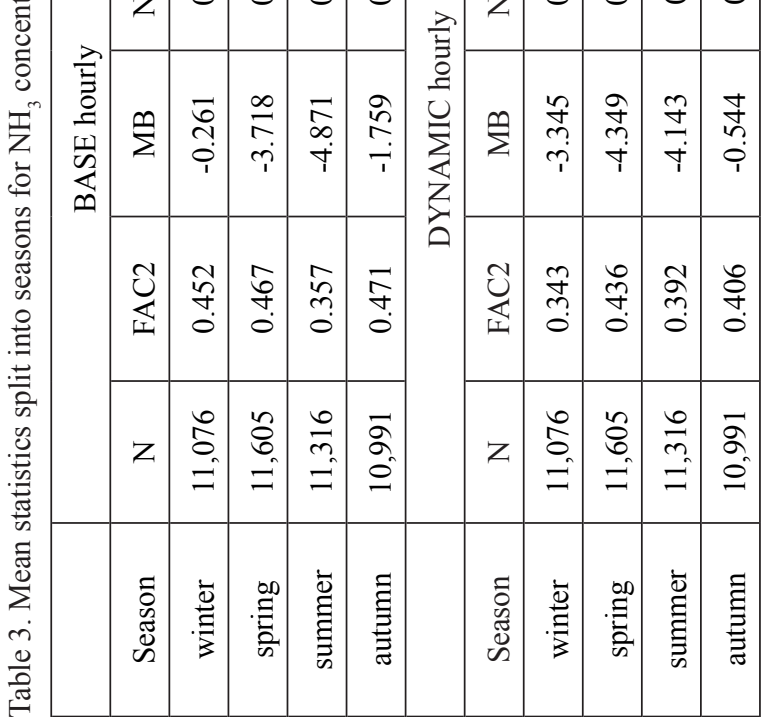


Table 4. Mean statistics split into seasons for $\mathrm{NH}_{4}^{+}$concentrations based on daily observations $(\mathrm{N})$ from all sites.

\begin{tabular}{|c|c|c|c|c|c|}
\hline \multicolumn{6}{|c|}{ BASE daily } \\
\hline Season & N & FAC2 & MB & NMGE & R \\
\hline winter & 1,921 & 0.433 & -0.326 & 0.638 & 0.586 \\
\hline spring & 1,983 & 0.432 & -0.142 & 0.671 & 0.590 \\
\hline summer & 1,915 & 0.391 & 0.058 & 0.983 & 0.220 \\
\hline autumn & 1,801 & 0.379 & 0.446 & 0.994 & 0.524 \\
\hline \multicolumn{5}{|c|}{ DYNAMIC daily } \\
\hline Season & $\mathrm{N}$ & FAC2 & MB & NMGE & R \\
\hline winter & 1,921 & 0.340 & -0.647 & 0.681 & 0.586 \\
\hline spring & 1,983 & 0.375 & -0.571 & 0.653 & 0.587 \\
\hline summer & 1,915 & 0.368 & -0.279 & 0.784 & 0.221 \\
\hline autumn & 1,801 & 0.424 & -0.085 & 0.697 & 0.523 \\
\hline
\end{tabular}

Table 5. Mean statistics split into seasons for $\mathrm{NO}_{3}{ }_{3}^{-}$concentrations based on daily observations $(\mathrm{N})$ from all sites.

\begin{tabular}{|c|c|c|c|c|c|}
\hline \multicolumn{5}{|c|}{ BASE daily } \\
\hline Season & $\mathrm{N}$ & FAC2 & MB & NMGE & $\mathrm{R}$ \\
\hline winter & 1,602 & 0.428 & 0.481 & 0.714 & 0.630 \\
\hline spring & 1,571 & 0.352 & 0.880 & 0.852 & 0.657 \\
\hline summer & 1,510 & 0.179 & 0.876 & 1.606 & 0.270 \\
\hline autumn & 1,534 & 0.250 & 2.851 & 1.822 & 0.547 \\
\hline \multicolumn{5}{|c|}{ DYNAMIC daily } \\
\hline Season & $\mathrm{N}$ & FAC2 & MB & NMGE & $\mathrm{R}$ \\
\hline winter & 1,602 & 0.448 & -0.770 & 0.594 & 0.631 \\
\hline spring & 1,571 & 0.400 & -0.586 & 0.632 & 0.654 \\
\hline summer & 1,510 & 0.218 & -0.028 & 1.087 & 0.273 \\
\hline autumn & 1,534 & 0.364 & 0.991 & 0.992 & 0.546 \\
\hline
\end{tabular}

presented in Table 2. For the BASE simulation and hourly temporal resolution the best results are obtained for spring - including the lowest NMGE $\left(0.680 \mu \mathrm{g} \mathrm{m}^{-3}\right)$ and the highest FAC2 (0.458) and R (0.419) - whereas the worst FAC2 (0.358) and R (0.274) is obtained for the summer period. For the same simulation, for daily and monthly comparison, the statistics change significantly, e.g., correlation coefficient is higher for all seasons and FAC2 is higher for spring, summer, and autumn in comparison to hourly statistics. For DYNAMIC simulation and hourly temporal resolution the results are similar to BASE, with the highest FAC2 (0.419) and R (0.387) in the spring; however, the lowest NMGE is not in spring but in summer.

There are no clear differences in model performance between the BASE and DYNAMIC simulation when all stations are considered. Both simulations underestimate
Table 6. Mean statistics split into seasons for $\mathrm{SO}_{4}{ }^{2-}$ - concentrations based on daily observations $(\mathrm{N})$ from all sites.

\begin{tabular}{|c|c|c|c|c|c|}
\hline \multicolumn{7}{|c|}{ BASE daily } \\
\hline Season & N & FAC2 & MB & NMGE & R \\
\hline winter & 3,206 & 0.032 & -1.733 & 0.949 & 0.135 \\
\hline spring & 3,258 & 0.116 & -1.289 & 0.810 & 0.393 \\
\hline summer & 3,121 & 0.339 & -0.978 & 0.686 & 0.369 \\
\hline autumn & 3,059 & 0.155 & -1.210 & 0.842 & 0.384 \\
\hline \multicolumn{5}{|c|}{ DYNAMIC daily } \\
\hline Season & N & FAC2 & MB & NMGE & R \\
\hline winter & 3,206 & 0.014 & -1.771 & 0.969 & 0.138 \\
\hline spring & 3,258 & 0.045 & -1.418 & 0.883 & 0.392 \\
\hline summer & 3,121 & 0.173 & -1.204 & 0.793 & 0.369 \\
\hline autumn & 3,059 & 0.089 & -1.310 & 0.900 & 0.386 \\
\hline
\end{tabular}

measured concentrations for all seasons and have similar NMGE (about $0.7 \mu \mathrm{g} \mathrm{m}^{-3}$ ). For hourly, daily, and monthly values MB in summer and autumn and NMGE in winter and summer is lower for DYNAMIC than for BASE. Simultaneously, the DYNAMIC simulation gives worse performance in spring for each temporal resolution.

If only agricultural stations are compared with hourly measurements, the DYNAMIC simulation shows improved performance in terms of FAC2 and NMGE. The same is for daily and monthly statistics, but the general tendency for underestimation of observed $\mathrm{NH}_{3}$ concentrations is present for both the BASE and DYNAMIC runs. For summer, the DYNAMIC simulation shows a smaller bias if compared with BASE.

In the case of aerosols $\left(\mathrm{NH}_{4}^{+}, \mathrm{NO}_{3}^{-}, \mathrm{SO}_{4}^{2-}\right.$, Tables 4-6), the DYNAMIC simulation underestimates measured concentrations for all species $(\mathrm{MB}<0)$. The BASE simulation underestimates $\mathrm{NH}_{4}^{+}$concentrations in winter and spring, underestimates $\mathrm{SO}_{4}^{2-}$ for all seasons, and overestimates $(\mathrm{MB}>0) \mathrm{NO}_{3}{ }^{-}$for all seasons. Generally, the best performance (the lowest NMGE and the highest $\mathrm{R}$ ) is for $\mathrm{NO}_{3}$ - for DYNAMIC. There is a significant improvement between the BASE and DYNAMIC simulation for $\mathrm{NO}_{3}^{-}$. FAC2 and NMGE are improved for the DYNAMIC run during all seasons, e.g., in winter from 0.25 to 0.36 for FAC2 and from 10.8 to $0.99 \mu \mathrm{m}^{-3}$ for NMGE. A decrease in NMGE, between BASE and DYNAMIC, is also observed for $\mathrm{NH}_{4}+$ in spring, summer, and autumn. The BASE run gives better model-measurement agreement for $\mathrm{SO}_{4}^{2-}$.

The performance of the BASE and DYNAMIC runs for hourly, daily, and monthly measurements is summarized, based on all available stations, in Taylor plots (Fig. 7). Both runs poorly reproduce the observed variability of $\mathrm{NH}_{3}$ concentrations, which is shown by lower-than-observed standard deviation for all temporal resolutions. For daily concentrations of aerosols (Fig. 7), there is a clear improvement for standard deviation of $\mathrm{NO}_{3}^{-}$if BASE and DYNAMIC runs are compared, 

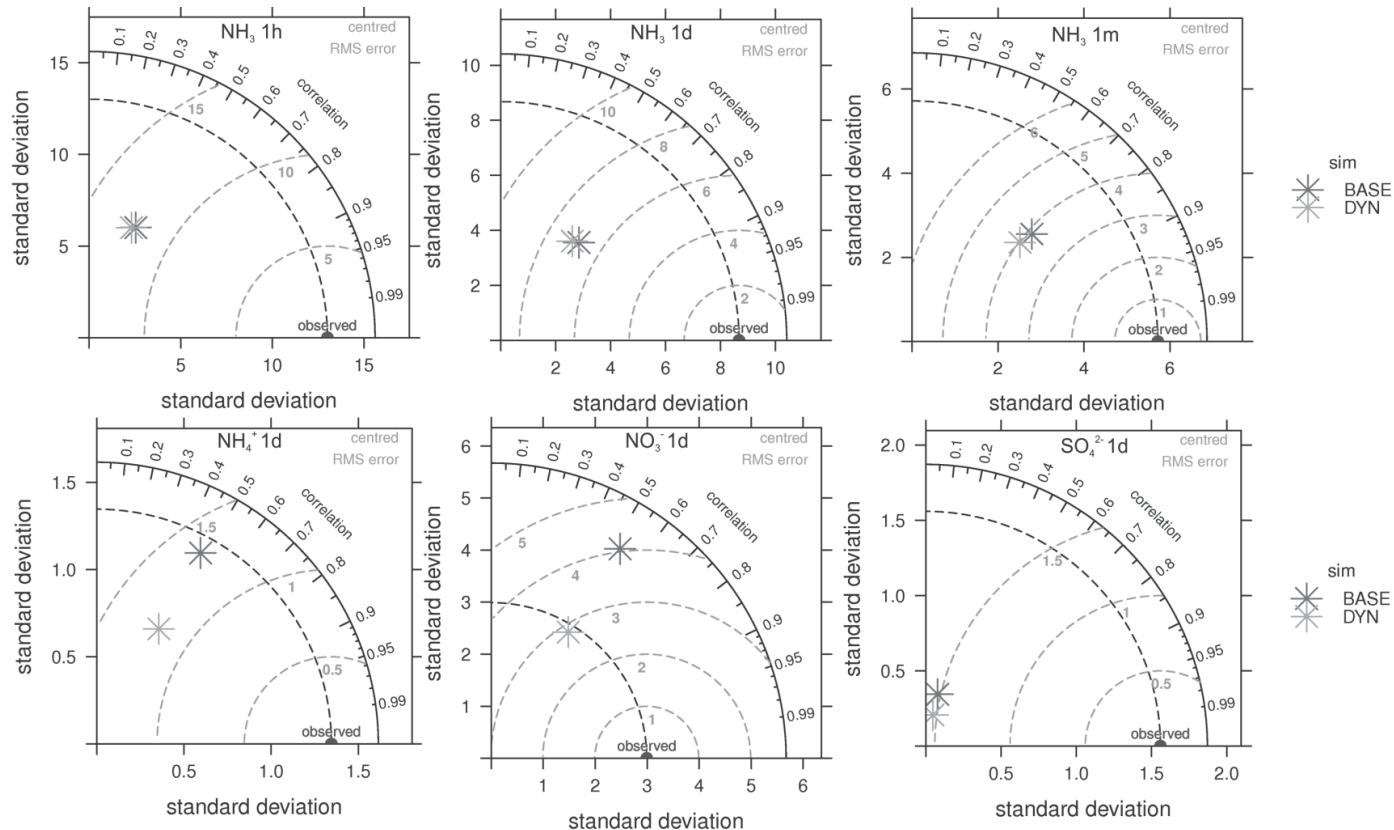

Fig. 7. Taylor plots based on all available observations. Upper row for $\mathrm{NH}_{3}$, from left to right: hourly, daily, monthly. Lower row for daily data, from left to right: $\mathrm{NH}_{4}^{+}, \mathrm{NO}_{3}^{-}$, and $\mathrm{SO}_{4}{ }^{2-}$.

changing from 5.0 to 2.9 , where the measured value is 3.0 . There are very small changes of correlation coefficients between the simulations.

\section{Discussion and Conclusion}

We have observed that there is no clear improvement in model performance between the BASE and DYNAMIC simulation at the sites across Europe. Both simulations underestimate measured concentrations of $\mathrm{NH} 3$ for all seasons and have similar NMGE (about $0.7 \mu \mathrm{g} \mathrm{m}^{-3}$ ). However, for all temporal resolutions (hourly, daily, and monthly), NMGE in winter and summer is lower in the DYNAMIC simulation than in the BASE simulation. Simultaneously, the DYNAMIC simulation in general gives poorer agreement with observations during spring for all temporal resolutions. The analysis of the diurnal cycle of the $\mathrm{NH}_{3}$ concentration at, e.g., Harwell shows that the modelled hourly ammonia peaks are shifted toward the afternoon if compared with measurements. This occurs both for the BASE and DYNAMIC simulations, despite a strong peak of emissions in mid-day for the DYNAMIC approach. In the case of the DYNAMIC simulation, the model-measurement agreement is better (higher FAC2 and lower NMGE) if only agricultural stations are considered for all temporal resolutions. However, when we compare the model performance between BASE and DYNAMIC for agricultural stations, the tendency is similar as for all stations - underestimation of observations for both simulations and slightly better MB in summer and autumn, and NMGE in winter and summer for DYNAMIC. A similar modelled ammonia concentration pattern to that described above (peak shifted toward afternoon or evening hours) was reported by Wen et al. [57] for STILT-Chem simulations over southern Ontario in the United States, but the results were not evaluated against observations. The diurnal cycle of modelled ammonia concentrations for Cabauw station presented by Schaap et al. [58] and for selected EMEP stations by Aas et al. [59] shows better agreement with observations. These results are limited, however, to a selected station [58] or short period [59].

Results presented by Aas et al. [59] for June 2006 (Ispra, Harwell, Cabauw) show that both the modelled and measured cycles of $\mathrm{NH}_{3}$ typically have a maximum in early morning, and in general higher $\mathrm{NH} 3$ concentrations during daytime than night time, except at Ispra (IT01), where the modelled $\mathrm{NH}_{3}$ shows much lower variation than observed. A similar pattern was found for January 2007. However, the diurnal variation was clearly weaker in the measurements than in the model results.

These model results are typically based on a standard diurnal cycle of the ammonia emissions that assumes a factor of two higher emissions during the day than during the night. For regions with fertilized fields this might represent the diurnal cycle quite well, but in areas dominated by emissions from farms a more damped diurnal cycle in the emissions could be expected. The authors suggested that in order to obtain a better diurnal variation of ammonia concentrations the dispersion model could be coupled to a dynamic, mechanistic ammonia emissions model where the diurnal variation of emissions would depend on temperature, wind, and type of agricultural activity [59]. The suggested solution is exactly what we used in our study. However, the application of the Europewide default settings in the dynamic emissions model and at relatively coarse resolution did not lead to clear improvements in the modelled ammonia concentrations. 
The other drawback is the relatively coarse model grid resolution, which does not allow for detailed spatial separation between the source and background areas of $\mathrm{NH}_{3}[60]$.

The vertical distribution of modelled ammonia concentrations indicates, as expected, that the main source of ammonia in the air is at the surface. The maximum aerosol concentration appears after the peak of NH3 concentration, which may infer that the ammonia peaks are not related to the release of ammonia from aerosols. For aerosols $\left(\mathrm{NO}_{3}^{-}, \mathrm{NH}_{4}^{+}, \mathrm{SO}_{4}^{2-}\right)$ the maximum concentrations appear above the surface layer for selected episodes. The measured profile of ammonium, nitrate, and sulphate concentrations from the EUCAARI-LONGREX campaign, as reported by Kulmala et al. [61], shows a similar pattern. The concentration peak appears above the surface layer but not higher than $2 \mathrm{~km}$ above the ground layer.

Aerosol concentrations of $\mathrm{NH}_{4}^{+}, \mathrm{NO}_{3}^{-}$, and $\mathrm{SO}_{4}^{2-}$ from the DYNAMIC simulation are underestimated for all species, with annual MB based on daily values equal to $-0.40,-0.10$, and $-1.43 \mu \mathrm{g} \mathrm{m}-3$, respectively. Underestimations of aerosol concentrations were also simulated by the LOTOS-EUROS model for the Cabauw station [58]. MB based on hourly values for 2007 was equal to $-0.60,-2.2$, and -1.1 for $\mathrm{NH}_{4}^{+}, \mathrm{NO}_{3}^{-}$, and $\mathrm{SO}_{4}^{-2}$. Our results show a significant improvement between the BASE and DYNAMIC simulations for $\mathrm{NO}_{3}^{-}$. FAC2 and NMGE is improved for all seasons, e.g., in autumn from 0.25 to 0.36 for FAC2 and from 1.82 to $0.99 \mu \mathrm{m}^{-3}$ for NMGE.

For each analysed episode (March, April, July, and October) the surface ammonia concentrations are negatively correlated with the planetary boundary layer height - midday peaks of PBLH are accompanied by a local minimum of modelled $\mathrm{NH}_{3}$ concentrations. It has been previously shown that PBLH is an important variable for air quality modelling, which is often difficult to simulate accurately in numerical models [62-63]. Determining the PBLH is important in atmospheric numerical models, because it is used in other physical parameterisations and because it is a governing parameter for the distribution of trace gases [64]. Meteorological conditions are known to exert a direct impact on air quality simulation. Han et al. [65] showed that the difference in modelled vertical turbulent mixing is one of the main reasons for the discrepancy in pollutant concentration among the chemical transport models. The purpose of PBL parameterization is to redistribute energy and humidity in the PBL. Both humidity and temperature have an impact on ammonia concentrations. Previous studies suggest that the YSU scheme in WRF [66], which was also applied in our study, tends to overestimate the PBL height [63]. The highest variability between measurements and modelled data are in the midday and are rather constant at night [67]. Kim et al. [40] have found that the YSU and MYJ schemes in WRF overestimate, while ACM2 and MYNN underestimate PBL height. Their study over Greater Paris indicates that the modelled mean PBLH differs significantly among the schemes and by more than $300 \%$ between the MYNN and YSU. Overestimation of PBLH in chemical transport models like, e.g., WRF-Chem, might cause an overestimation of mixing layer depth and result in an underestimation of modelled pollution concentrations. The latter might be especially relevant for emissions that are released from the surface. Based on the meteograms plotted here, we suggest that the vertical extent of the PBL will directly impact the overall concentration of ammonia in the PBL layer. The PBL physics - and therefore also the choice of parameterisation - must therefore affect the ammonia concentrations both at the surface as well as throughout the PBL layer.

The potential higher bias in T2 from the WRF model, reported for Central Europe for summer season by Skjøth et al. [42] and Kryza et al. [43], will impact the modelled ammonia concentrations. The $\mathrm{NH}_{3}$ measuring stations in this region (e.g., in Poland) reveals an increased bias in ammonia concentration for the DYNAMIC simulation, for which $\mathrm{NH}_{3}$ emissions depends on air temperature if compared to the BASE simulation during the summer. However, this increased bias for the DYNAMIC simulation is also present for the spring. This suggests that the bias in ammonia concentrations is not related to a bias in temperatures alone, but is a combination of effects also related to the coarse grid applied here and how the ammonia emissions are distributed between different emissions sectors implemented into the dynamic emissions model, which are then affected by meteorological factors. Several studies showed that significant differences may occur between measured and modelled ammonia concentrations due to the grid size resolution. The highly localized nature of NH3 emissions is especially causing this difference [68-69].

The meteograms for aerosols suggest that the high night-time concentrations are not due to the release of ammonia from nitrogen-containing aerosols. The most likely cause of these high concentrations is that the flux of ammonia from the surface is too high at night. The flux of ammonia from agricultural sources away from the surface is mainly dependent on two processes: direct emissions due to volatilization (e.g., higher temperatures give higher emissions) and the effect of turbulence. The parameterisation we used does not provide an increase of $100 \%$ in emissions from manure that is applied to the field as it is directly linked to previous studies with the ALFAM model $[16,50]$, and the parameterisation does not take into account turbulence at the surface, but instead uses a wind speed dependency taken from the ALFAM model [50]. The combination of the temperature and wind speed effect has the consequence that there will be a continuous release of ammonia during the night, even during low temperatures and at low wind speeds. Therefore, it must be expected that this limitation causes a redistribution of emissions from day to night, thereby reducing the diurnal emissions profile and causing a lower daytime peak. If this hypothesis is correct, then new field experiments as a replacement of older experimental data from the ALFAM would be appropriate. Such observations could be used 
to update the effect of environmental parameters on the volatilization of ammonia from fields within the emissions model.

Due to the implementation of meteorological conditions in the DYNAMIC approach, a significant proportion of the emissions was moved from the winter period to spring and autumn. However, the spring and autumn peaks of modelled concentrations are often misplaced in time if compared with measurements. This can be improved by replacing the Europe-wide default setting, used here after Skjøth et al. [18] with national practice and regulations for individual countries. Studies of the negative effects related to high ammonia have shown that plant sensitivity to ammonia might depend on the evolution of the plants and hence can vary throughout the seasons [70]. If CTMs are going to be used for environmental assessments that focus on the seasonal and also the short-term variations of ammonia, then it is recommended to adjust the Europescale settings in the model with country or regional-scale settings over the target areas.

The spatial distribution of ammonia emissions varies substantially in time between the BASE and DYNAMIC simulations. This difference is especially noticed for countries with high ammonia emissions. High ammonia concentrations (above $10 \mu \mathrm{g} \mathrm{m}^{-3}$ ) occur during the winter obtained with the BASE simulation for northern Italy, northern France, Germany, and Poland. These high concentrations are caused by both emissions (higher than in the DYNAMIC simulation) and meteorological conditions, such as low PBL height that decrease dilution and low temperatures that decrease chemical conversion. In April, for the same areas, much higher concentrations are modelled with the DYNAMIC simulation than with the BASE simulation. This is related to high ammonia emissions during this period caused by the application of manure and fertilizers in growing crops. Simultaneously for April, the DYNAMIC simulation calculated the highest ammonia concentrations for many European regions, presented in this study as the number of day with the highest hourly concentrations. Similar findings on spatial variability were also documented by Hamaoui-Laguel et al. [25] for a study conducted over France. Their study focused on the effect of emissions from mineral fertilizers and these results showed that the spatial pattern was highly dependent on actual meteorological conditions. These results, obtained with the CHIMERE model, the results by Wen et al. [57] with STILT-Chem, our results with WRF-Chem, and previous studies with this emissions model all suggest that it is important to have a direct connection between hourly meteorological variables and the level of ammonia emissions. The comparison with the satellite product suggests that the model simulations qualitatively agree with peak concentrations in Central Europe and Northern Europe, but the picture is more diverse in France, Spain, and Portugal. In these regions the peak concentration can be in either spring or summer. Conceptually, the emissions model forces a nationwide spring peak in ammonia concentrations in these regions as the farmers are expected to apply a significant part of the manure during spring. However, significant fractions of the agricultural landscape in France, Italy, Spain, and Portugal, according to the CLC data set, are not crops under rotation (e.g., wheat, barley, and sunflower, which need annual harvest and tiling), but instead permanent crops, pastures, or complex cultivation patterns. These areas will typically not receive a substantial application of manure during spring but will instead have higher emissions during summer due to grazing and because there is no need from an agricultural point of view to apply the manure during spring. This suggests that the Europewide calculations can be improved substantially in this area, if the land cover type is included in the emissions model, which is currently not the case. The lack of spring peak over the Pannonian Plain and the Balkan region in the simulation could partly be related to the same issue as a land cover type. However, large parts of the Pannonian Plain are covered by crops under rotation. A detailed inspection of data from the greenhouse gas and air pollution interactions and synergies (GAINS) model system shows that the storage facilities in countries like Croatia, Bulgaria, and Hungary are estimated to hold 2-4 months of manure. This will force very large amounts of manure to be applied during summer. The information in GAINS also indicates that the manure is to a large degree applied to permanent grassland, which often happens during summer. This suggests that the emissions model can be improved by taking into account the number of applications that farmers have to make during one production year (as dictated by the storage facilities) and the type of land cover that typically receives the manure (e.g., permanent grassland or crops under rotation).

Our study does not include bi-directional exchange, which can further influence the modelled ammonia concentrations. A recent study provided by Zhu et al. [21] suggests that although the implementation of bi-directional exchange leads to a better fundamental description of $\mathrm{NH}_{3}$ emissions from fertilizers, it does not uniformly improve estimation of $\mathrm{NH}_{3}$ concentrations, $\mathrm{NH}_{4}^{+}$wet deposition, and nitrate aerosol concentrations. However, Bash et al. [24] reported that an implementation of bidirectional exchange of $\mathrm{NH}_{3}$ improved the simulations of NHx wet deposition and improved the simulation of ambient nitrate aerosol concentrations for the United States. Wichink Kruit et al. [23] showed that with the new description in the LOTOS-EUROS model, which includes bi-directional surface-atmosphere exchange, the modelled ammonia concentrations increase almost everywhere, in particular in agricultural source areas. The reason for this is that by using a compensation point the ammonia lifetime and transport distance is increased. A comparison with measurements shows that the model results better represent measured ammonia concentrations; however the concentrations in nature areas are slightly overestimated, while the concentrations in agricultural sources are underestimated.

Our study indicates that the application of dynamic ammonia emissions at a relatively course resolution $(36 \times 36 \mathrm{~km})$ and based on the Europe-wide default 
settings into the chemical transport model may not lead to improvement of model performance. The main advantages of the dynamic approach are:

1) Better representation of $\mathrm{NH}_{3}$ concentrations in summer and autumn.

2) Improvement in representation of the spring peak in $\mathrm{NH}_{3}$ concentrations - the peak is shorter if compared with the BASE run and better reflects the observed high values of $\mathrm{NH}_{3}$ concentrations for agricultural stations. This spring peak gradually progresses northward according to the progression of crop growth and is in agreement with both satellite [55] and ground-based observations [50].

3) Capture of individual peaks in March, July, and August for non-agricultural stations.

4) An automatic conversion from a spring peak into a summer peak in areas that are dominated by grazing animals such as in Southern Europe or Wales in the UK - thus as a consequence with a limited spring peak. This, however, require subnational information in countries like France, Portugal, Spain, and Italy.

For further improvement of the ammonia concentrations modelled with WRF-Chem we suggest using a nested approach with higher spatial resolution and to take into account national practice and regulations in the emissions model. More importantly, the comparison with the satellite product by Van Damme et al. [56] and the diverse land cover pattern given in the CLC data set strongly indicates that it is important to consider land cover type in the emissions model and to include sub-national data sets on agricultural management. Technically, the model was developed for this approach [16, 50], but a method to generate the needed information on a Europe-wide scale has not yet been developed as we here rely on nation-wide numbers from the GAINS system. With an extension that relies on sub-national information, the areas with crops under rotation can receive spring manure while grasslands and pasture mainly will have their emissions peak during summer due to summer applications and grazing animals. Nevertheless, the comparison also suggests that the Europe-wide emissions model works well in many European countries, in particular in the geographical areas with extensive amounts of crops under rotation and an intensive agriculture with production systems that allow for substantial storage and as a consequence large amounts of spring application. The study also shows that the current description of the diurnal cycle of the ammonia concentration from agricultural fields is not sufficiently accurate, and more research is needed in order to improve the processes that describe the emissions from fields. The results suggest that the governing processes in relation to the diurnal cycle are the atmospheric mixing and the stronger daily pattern of ammonia emissions, e.g., through increased evaporation or increased fluxes from the surface. The latter is still quite difficult to observe as only very few sites measure ammonia concentrations with a sufficiently high temporal resolution required for a proper evaluation and developments of better emissions models. New field experiments as a replacement of older experimental data would be appropriate in order to update an observational assessment of the emissions process parameterised in the model, and this is one of the expected outcomes and objectives of the ECLAIRE project.

\section{Acknowledgements}

This study has received support from the EU project ECLAIRE (No. 282910), the Polish National Science Centre through project No. UMO-2013/09/B/ST10/00594, the Danish Strategic Research Council project ECOCLIM (No. 10-093901), the SUPREME project from the Danish Research Council (No. 0602-02550B), and the European Commission (No. CIG631745). Additional support was provided through intramural funding by the participating institutes.

\section{References}

1. BEHERA S.N., SHARMA M., ANEJA V.P., BALASUBRAMANIAN R. Ammonia in the atmosphere: A review on emissions sources, atmospheric chemistry and deposition on terrestrial bodies. Environmental Science and Pollution Research, 20, 2013.

2. HERTEL O., SKJØTH C. A., REIS S., BLEEKER A., HARRISON R.M., CAPE J.N., FOWLER D., SKIBA U., SIMPSON D., JICKELLS T., KULMALA M., GYLDENKÆRNE S., SØRENSEN L.L., ERISMAN J.W. Governing processes for reactive nitrogen compounds in the European atmosphere. Biogeosciences, 9, 12, 2012.

3. BANZHAF S., SCHAAP M., WICHINK KRUIT R.J., DENIER VAN DER GON H.A.C., STERN R., BUILTJE, P.J.H. Impact of emissions changes on secondary inorganic aerosol episodes across Germany. Atmospheric Chemistry and Physics, 13, 23, 2013.

4. REIS S., PINDER R.W., ZHANG M., LIJIE G., SUTTON M. A. Reactive nitrogen in atmospheric emissions inventories. Atmospheric Chemistry and Physics, 9, 19, 2009.

5. BESSAGNET B., BEAUCHAMP M., GUERREIRO C., DE LEEUW F., TSYRO S., COLETTE A., MELEUX F., ROUÏL L., RUYSSENAARS P., SAUTER F., VELDERS G.J.M., FOLTESCU V.L., VAN AARDENNE J. Can further mitigation of ammonia emissions reduce exceedances of particulate matter air quality standards? Environmental Science \& Policy, 44, 2014.

6. ERISMAN J.W., SUTTON M.A., GALLOWAY J., KLIMONT Z., WINIWARTER W. How a century of ammonia synthesis changed the world. Nature Geoscience, $\mathbf{1}, 10,2008$

7. BRANDT J., SILVER J.D., CHRISTENSEN J.H., ANDERSEN M.S., BØNLØKKE J.H., SIGSGAARD T., GEELS C., GROSS A., HANSEN A.B., HANSEN K.M., HEDEGAARD G.B., KAAS E., FROHN L.M. Contribution from the ten major emissions sectors in Europe and Denmark to the health-cost externalities of air pollution using the EVA model system - an integrated modelling approach. Atmospheric Chemistry and Physics, 13, 15, 2013.

8. BOUWMAN A.F., LEE D.S., ASMAN W.A.H., DENTENER F.J., VAN DER HOEK K.W., OLIVIER J.G.J. A global high-resolution emissions inventory for ammonia. Global Biogeochemical Cycles, 11, 4, 1997. 
9. STEVENS C.J., DISE N.B., MOUNTFORD J.O., GOWIN, D.J. Impact of nitrogen eposition on the species richness of grasslands. Science (New York, N.Y.), 303, 5665, 2004.

10. BOBBINK R., HICKS K., GALLOWAY J., SPRANGER T., ALKEMADE R., ASHMORE M., BUSTAMANTE M., CINDERBY S., DAVIDSON E., DENTENER F., EMMETT B., ERISMAN J.-W., FENN M., GILLIAM F. Global assessment of nitrogen deposition effects on terrestrial plant diversity: a synthesis. Ecological Applications, 20, 1, 2010.

11. TØRSETH K., AAS W., BREIVIK K., FJÆRAA A.M., FIEBIG M., HJELLBREKKE A.G., LUND MYHRE C., SOLBERG S., YTTRI K.E. Introduction to the European Monitoring and Evaluation Programme (EMEP) and observed atmospheric composition change during 19722009. Atmospheric Chemistry and Physics, 12, 12, 2012.

12. FLECHARD C.R., MASSAD R.-S., LOUBET B., PERSONNE E., SIMPSON D., BASH J.O., COOTER E.J., NEMITZ E., SUTTON M.A. Advances in understanding, models and parameterizations of biosphere-atmosphere ammonia exchange. Biogeosciences, 10, 7, 2013.

13. HANSEN K., PRYOR S.C., BOEGH E., HORNSBY K.E., JENSEN B., SØRENSEN L.L. Background concentrations and fluxes of atmospheric ammonia over a deciduous forest. Agricultural and Forest Meteorology, 214-215, 2015.

14. SKJØTH C. A., GEELS C. The effect of climate and climate change on ammonia emissions in Europe. Atmospheric Chemistry and Physics, 13, 1, 2013.

15. MONTENY G.J., ERISMAN J.W. Ammonia emissions from dairy cow buildings: a review of measurement techniques, influencing factors. Netherlands Journal of Agricultural Science, 46, 1998

16. GYLDENKÆRNE S., SKJØTH C.A., HERTEL O., ELLERMANN T. A dynamical ammonia emissions parameterization for use in air pollution models. Journal of Geophysical Research, 110, D7, 2005.

17. SUTTON M.A., REIS S., RIDDICK S.N., DRAGOSITS U., NEMITZ E., THEOBALD M.R., TANG Y.S., BRABAN C.F., VIENO M., DORE A.J., MITCHELL R.F., WANLESS S., DAUNT F., FOWLER D. Towards a climatedependent paradigm of ammonia emissions and deposition. Philosophical transactions of the Royal Society of London. Series B, Biological sciences, 368, 1621, 2013.

18. SKJØTH C.A., GEELS C., BERGE H., GYLDENKÆRNE S., FAGERLI H., ELLERMANN T., FROHN L.M., CHRISTENSEN J., HANSEN K.M., HANSEN K., HERTEL O. Spatial and temporal variations in ammonia emissions - a freely accessible model code for Europe. Atmospheric Chemistry and Physics, 11, 11, 2011.

19. WERNER M., AMBELAS SKJØTH C., KRYZA M., DORE A. J. Understanding emissions of ammonia from buildings and application of fertilizers: an example from Poland. Biogeosciences Discussions, 12, 2, 2015.

20. KIRTMAN B., POWER S.B., ADEDOYIN J.A., BOER G.J., BOJARIU R., CAMILLONI I., DOBLAS-REYES F.J., FIORE A.M., KIMOTO M., MEEHL G.A., PRATHER M., SARR A., SCHÄR C., SUTTON R. Near-term Climate Change: Projections and Predictability. In: Climate Change 2013: The Physical Science Basis. Contribution of Working Group I to the Fifth Assessment Report of the Intergovernmental Panel on Climate Change. In T.F. Stocker, D. Qin, G.-K. Plattner, M. Tignor, S.K. Allen, J. Boschung, A. Nauels, Y. Xia, V. Bex, P.M. Midgley (eds). Contribution of Working Group I to the Fifth Assessment Report of the Intergovernmental Panel on Climate ChangeCambridge University Press, Cambridge, United Kingdom and New York, NY, USA, pp. 76, 2013.
21. ZHU L., HENZE D., BASH J., JEONG G.-R., CADYPEREIRA K., SHEPHARD M., LUO M., PAULOT F., CAPPS S. Global evaluation of ammonia bi-directional exchange. Atmospheric Chemistry and Physics Discussions, $15,2015$.

22. GILLILAND A.B., DENNIS R.L., ROSELLE S.J., AND PIERCE T.E. Seasonal NH3 emissions estimates for the eastern United States based on ammonium wet concentrations and an inverse modeling method. Journal of Geophysical Research, 108, D15, 2003.

23. WICHINK KRUIT R.J., SCHAAP M., SAUTER F.J., VAN ZANTEN M.C., VAN PUL W.A.J. Modeling the distribution of ammonia across Europe including bi-directional surfaceatmosphere exchange. Biogeosciences, 9, 12, 2012.

24. BASH J.O., COOTER E.J., DENNIS R.L., WALKER J.T., AND PLEIM J. E. Evaluation of a regional air-quality model with bidirectional $\mathrm{NH}_{3}$ exchange coupled to an agroecosystem model. Biogeosciences, 10, 3, 2013.

25. HAMAOUI-LAGUEL L., MELEUX F., BEEKMANN M., BESSAGNET B., GÉNERMONT S., CELLIER P., LÉTINOIS L. Improving ammonia emissions in air quality modelling for France. Atmospheric Environment, 92, 2014.

26. HANSEN K., SØRENSEN L.L., HERTEL O., GEELS C., SKJØTH C.A., JENSEN B., BOEGH E. Ammonia emissions from deciduous forest after leaf fall. Biogeosciences, 10, 7, 2013

27. RIDDICK S.N., BLACKALL T.D., DRAGOSITS U., DAUNT F., BRABAN C.F., TANG Y.S., MACFARLANE W., TAYLOR S., WANLESS S., SUTTON M.A. Measurement of ammonia emissions from tropical seabird colonies. Atmospheric Environment, 89, 2014.

28. GRELL G., PECKHAM S.E., SCHMITZ R., MCKEEN STUART FROST G., SKAMAROCK W.C., EDER B. Fully coupled "online" chemistry within the WRF model. Atmospheric Environment, 39, 37, 2005.

29. FAST J.D., GUSTAFSON W.I., EASTER R.C., ZAVERI R.A., BARNARD J.C., CHAPMAN E.G., GRELL G.A., AND PECKHAM S.E. Evolution of ozone, particulates, and aerosol direct radiative forcing in the vicinity of Houston using a fully coupled meteorology-chemistry-aerosol model. Journal of Geophysical Research, 111, D21, 2006.

30. FORKEL R., BALZARINI A., BARÓ R., BIANCONI R., CURCI G., JIMÉNEZ-GUERRERO P., HIRTL M., HONZAK L., LORENZ C., IM U., PÉREZ J.L., PIROVANO G., SAN JOSÉ R., TUCCELLA P. Analysis of the WRFChem contributions to AQMEII phase2 with respect to aerosol radiative feedbacks on meteorology and pollutant distributions. Atmospheric Environment, 115, 2014.

31. STOCKWELL W.R., MIDDLETON P., CHANG J.S., TANG $\mathrm{X}$. The second generation regional acid deposition model chemical mechanism for regional air quality modeling. Journal of Geophysical Research, 95, D10, 1990.

32. ACKERMANN I.J., HASS H., MEMMESHEIMER M., EBEL A., BINKOWSKI F.S., SHANKAR U. Modal aerosol dynamics model for Europe. Atmospheric Environment, 32, 17,1998

33. SCHELL B., ACKERMANN I.J., HASS H., BINKOWSKI F.S., EBEL A. Modeling the formation of secondary organic aerosol within a comprehensive air quality model system. Journal of Geophysical Research: Atmospheres, 106, D22, 2001.

34. FORKEL R., WERHAHN J., HANSEN A.B., MCKEEN S., PECKHAM S., GRELL G., SUPPAN P. Effect of aerosolradiation feedback on regional air quality - A case study with WRF/Chem. Atmospheric Environment, 53, 2012. 
35. ZHANG Y., WEN X.-Y., JANG C.J. Simulating chemistryaerosol-cloud-radiation-climate feedbacks over the continental U.S. using the online-coupled Weather Research Forecasting Model with chemistry (WRF/Chem). Atmospheric Environment, 44, 29, 2010.

36. ELLIS R.A., MURPHY J.G., MARKOVIC M.Z., VANDENBOER T.C., MAKAR P. A., BROOK J., MIHELE $\mathrm{C}$. The influence of gas-particle partitioning and surfaceatmosphere exchange on ammonia during BAQS-Met. Atmospheric Chemistry and Physics, 11, 2011.

37. MIGLIETTA M.M., THUNIS P., GEORGIEVA E., PEDERZOLI A., BESSAGNET B., TERRENOIRE E., AND COLETTE A. Evaluation of WRF model performance in different European regions with the DELTA-FAIRMODE evaluation tool. International Journal Of Environment And Pollution, 50, 1/2/3, 2012.

38. KATRAGKOU E., GARCÍA-DÍEZ M., VAUTARD R., SOBOLOWSKI S., ZANIS P., ALEXANDRI G., CARDOSO R.M., COLETTE A., FERNANDEZ J., GOBIET A., GOERGEN K., KARACOSTAS T., KNIST S., MAYER S. Regional climate hindcast simulations within EURO-CORDEX: evaluation of a WRF multi-physics ensemble. Geoscientific Model Development, 8, 3, 2015.

39. WAŁASZEK K., KRYZA M., WERNER M. Evaluation of the WRF meteorological model results during a high ozone episode in SW Poland - the role of model initial conditions. International Journal Of Environment And Pollution, 54, $2 / 3 / 4,2014$

40. KIM Y., SARTELET K., RAUT J.C., CHAZETTE P. Evaluation of the Weather Research and Forecast/Urban Model Over Greater Paris. Boundary-Layer Meteorology, 149, 2013.

41. WARRACH-SAGI K., SCHWITALLA T., WULFMEYER V., BAUER H.-S. Evaluation of a climate simulation in Europe based on the WRF-NOAH model system: precipitation in Germany. Climate Dynamics, 41, 3-4, 2013.

42. SKJØTH C.A., WERNER M., KRYZA M., ADAMSGROOM B., WAKEHAM A., LEWIS M., KENNEDY R. Quality of the governing temperature variables in WRFChem in relation to simulation of primary biological aerosols. Advances in Meteorology, vol. 2015, Article ID 412658, 2015.

43. KRYZA M., WAŁASZEK K., OJRZYŃSKA H., SZYMANOWSKI M., WERNER M., DORE A.J. High resolution dynamical downscaling of ERA-Interim using the WRF regional climate model (Part 1) - model configuration and statistical evaluation for the 1981-2010 period. Pure and Applied Geophysics, doi:10.1007/s00024-016-1272-5, 2016.

44. MOONEY P.A., MULLIGAN F.J., FEALY R. Evaluation of the Sensitivity of the Weather Research and Forecasting Model to Parameterization Schemes for Regional Climates of Europe over the Period 1990-95. Journal of Climate, 26, 3, 2013.

45. VIENO M., DORE A.J., STEVENSON D.S., DOHERTY R., HEAL M.R., REIS S., HALLSWORTH S., TARRASON L., WIND P., FOWLER D., SIMPSON D., SUTTON M.A. Modelling surface ozone during the 2003 heat-wave in the UK. Atmospheric Chemistry and Physics, 10, 16, 2010.

46. SANTOS-ALAMILLOS F.J., POZO-VÁZQUEZ D., RUIZARIAS J.A., LARA-FANEGO V., TOVAR-PESCADOR J. Analysis of WRF Model Wind Estimate Sensitivity to Physics Parameterization Choice and Terrain Representation in Andalusia (Southern Spain). Journal of Applied Meteorology and Climatology, 52, 7, 2013.
47. JIMÉNEZ P.A., DUDHIA J. On the Ability of the WRF Model to Reproduce the Surface Wind Direction over Complex Terrain. Journal of Applied Meteorology and Climatology, 52, 7, 2013.

48. KUENEN J.J.P., VISSCHEDIJK A.J.H., JOZWICKA M., AND DENIER VAN DER GON, H.A.C. TNO-MACC II emissions inventory, a multi-year (2003-2009) consistent high-resolution European emissions inventory for air quality modelling. Atmospheric Chemistry and Physics, 14, 20, 2014.

49. GEELS C., ANDERSEN H. V., AMBELAS SKJØTH C., CHRISTENSEN J.H., ELLERMANN T., LØFSTRØM P., GYLDENKÆRNE S., BRANDT J., HANSEN K.M., FROHN L.M., AND HERTEL O. Improved modelling of atmospheric ammonia over Denmark using the coupled modelling system DAMOS. Biogeosciences, 9, 7, 2012.

50. SKJØTH C.A., HERTEL O., GYLDENKÆRNE S., T., E. Implementing a dynamical ammonia emissions parameterization in the large-scale air pollution model ACDEP. Journal of Geophysical Research, 109, D6, 2004.

51. OLESEN J.E., AND PLAUBORG, F. MVTOOL Version 1.10 for Developing MARKVAND. Danish Institute of Plant and Soil Science, Research Centre Foulum, 1995.

52. SEEDORF J., HARTUNG J., SCHRÖDER M., LINKERT K.H., PEDERSEN S., TAKAI H., JOHNSEN J.O., METZ J.H.M., GROOT KOERKAMP P.W.G., UENK G.H., PHILLIPS V.R., HOLDEN M.R., SNEATH R.W., SHORT J.L. Temperature and Moisture Conditions in Livestock Buildings in Northern Europe. Journal of Agricultural Engineering Research, 70, 1, 1998.

53. SEEDORF J., HARTUNG J., SCHRÖDER M., LINKERT K.H., PEDERSEN S., TAKAI H., JOHNSEN J.O., METZ J.H.M., GROOT KOERKAMP P.W.G., UENK G.H., PHILLIPS V.R., HOLDEN M.R., SNEATH R.W., SHORT J.L.L. A Survey of Ventilation Rates in Livestock Buildings in Northern Europe. Journal of Agricultural Engineering Research, 70, 1, 1998.

54. ANDERSEN H.V., HOVMAND M.F. Measurements of ammonia and ammonium by denuder and filter pack. Atmospheric Environment, 28, 21, 1994.

55. VAN DAMME M., ERISMAN J.W., CLARISSE L., DAMMERS E., WHITBURN S., CLERBAUX C., DOLMAN A.J., COHEUR, P.-F. Worldwide spatiotemporal atmospheric ammonia $\left(\mathrm{NH}_{3}\right)$ columns variability revealed by satellite. Geophysical Research Letters, 42, 20, 2015.

56. VAN DAMME M., CLARISSE L., DAMMERS E., LIU X., NOWAK J.B., CLERBAUX C., FLECHARD C.R., GALY-LACAUX C., XU W., NEUMAN J.A., TANG Y.S., SUTTON M.A., ERISMAN J.W., COHEUR P.F. Towards validation of ammonia $\left(\mathrm{NH}_{3}\right)$ measurements from the IASI satellite. Atmospheric Measurement Techniques, 8, 2015.

57. WEN D., ZHANG L., LIN J.C., VET R., MORAN M.D. An evaluation of ambient ammonia concentrations over southern Ontario simulated with different dry deposition schemes within STILT-Chem v0.8. Geoscientific Model Development, 7, 2014

58. SCHAAP M., OTJES R.P., WEIJERS E.P. Illustrating the benefit of using hourly monitoring data on secondary inorganic aerosol and its precursors for model evaluation. Atmospheric Chemistry and Physics, 11, 21, 2011.

59. AAS W., TSYRO S., BIEBER E., BERGSTRÖM R., CEBURNIS D., ELLERMANN T., FAGERLI H., FRÖLICH M., GEHRIG R., MAKKONEN U., NEMITZ E., OTJES R., PEREZ N., PERRINO C. Lessons learnt from the first EMEP intensive measurement periods. Atmospheric Chemistry and Physics, 12, 17, 2012. 
60. DORE T., KRYZA M., HALL J.R., HALLSWORTH S., KELLER, V.J.D., VIENO, M., AND SUTTON, M.A. The influence of model grid resolution on estimation of national scale nitrogen deposition and exceedance of critical loads. Biogeosciences, 9, 2012.

61. KULMALA M., ASMI A., LAPPALAINEN H.K., BALTENSPERGER U., BRENGUIER J.L., FACCHINI M.C., HANSSON H.C., HOV O'DOWD C.D., PÖSCHL U., WIEDENSOHLER A., BOERS R., BOUCHER O., DE LEEUW G. General overview: European Integrated project on Aerosol Cloud Climate and Air Quality interactions (EUCAARI)-integrating aerosol research from nano to global scales. Atmospheric Chemistry and Physics, 11, 24, 2011.

62. DABBERDT W.F., CARROLL M.A., BAUMGARDNER D., CARMICHAEL G., COHEN R., DYE T., ELLIS J., GRELL G., GRIMMOND S., HANNA S., IRWIN J., LAMB B., MADRONICH S., MCQUEEN J. Meteorological Research Needs for Improved Air Quality Forecasting: Report of the 11th Prospectus Development Team of the U.S. Weather Research Program. Bulletin of the American Meteorological Society, 85, 4, 2004.

63. XIE B., FUNG J.C.H., CHAN A., LAU A. Evaluation of nonlocal and local planetary boundary layer schemes in the WRF model. Journal of Geophysical Research: Atmospheres, 117, D12, 2012.

64. GEELS C., GLOOR M., CIAIS P., BOUSQUET P., PEYLIN P., VERMEULEN A.T., DARGAVILLE R., AALTO T., BRANDT J., CHRISTENSEN J.H., FROHN L.M., HASZPRA L., KARSTENS U., RÖDENBECK C. Comparing atmospheric transport models for future regional inversions over Europe - Part 1: mapping the atmospheric
CO2 signals. Atmospheric Chemistry and Physics, 7, 13, 2007.

65. HAN Z., UEDA H., AN J. Evaluation and intercomparison of meteorological predictions by five MM5-PBL parameterizations in combination with three land-surface models. Atmospheric Environment, 42, 2, 2008.

66. HONG S.-Y., NOH Y., DUDHIA J. A New Vertical Diffusion Package with an Explicit Treatment of Entrainment Processes. Monthly Weather Review, 134, 9, 2006.

67. ÁCS F., GYÖNGYÖSI A.Z., BREUER H., HORVÁTH Á., MONA T. Sensitivity of WRF-simulated planetary boundary layer height to land cover and soil changes. Meteorologische Zeitschrift, 23, 3, 2014.

68. DORE T., VIENO M., TANG Y.S., DRAGOSITS U., DOSIO A., WESTON K.J., SUTTON M.A. Modelling the atmospheric transport and deposition of sulphur and nitrogen over the United Kingdom and assessment of the influence of $\mathrm{SO}_{2}$ emissions from international shipping. Atmospheric Environment, 41, 11, 2007.

69. VAN PUL W.A.J., VAN JAARSVELD J.A., VELLINGA O.S., VAN DEN BROEK M., SMITS M.C.J. The VELD experiment: An evaluation of the ammonia emissions and concentrations in an agricultural area. Atmospheric Environment, 42, 34, 2008.

70. SHEPPARD L.J., LEITH I.D., CROSSLEY A., DIJK N. VAN, CAPE J.N., FOWLER D., SUTTON M.A. LongTerm Cumulative Exposure Exacerbates the Effects of Atmospheric Ammonia on an Ombrotrophic Bog: Implications for Critical Levels. In M.A. Sutton, S. Reis, S.M.H. Baker (eds). Atmospheric AmmoniaDordrecht: Springer Netherlands, 2009. 
